UNIVERSIDADE DE SÃO PAULO

HOSPITAL DE REABILITAÇÃO DE ANOMALIAS CRANIOFACIAIS

CAROLINA MAIA SILVA

Investigação do histórico familial entre sujeitos com diferentes tipos de fissuras orofaciais não sindrômicas 

CAROLINA MAIA SILVA

\title{
Investigação do histórico familial entre sujeitos com diferentes tipos de fissuras orofaciais não sindrômicas
}

\author{
Dissertação apresentada ao Hospital de \\ Reabilitação de Anomalias Craniofaciais da \\ Universidade de São Paulo para obtenção do \\ título de Mestre em Ciências da Reabilitação, na \\ área de concentração Fissuras Orofaciais e \\ Anomalias Relacionadas.
}

Orientadora: Profa. Dra. Lucimara Teixeira das Neves 


\section{UNIVERSIDADE DE SÃO PAULO HOSPITAL DE REABILITAÇÃO DE ANOMALIAS CRANIOFACIAIS}

R. Silvio Marchione, 3-20

Caixa Postal: 1501

17012-900 - Bauru - SP - Brasil

Prof. Dr. Vahan Agopyan - Reitor da USP

Dr. Carlos Ferreira dos Santos - Superintendente do HRAC /USP

Autorizo, exclusivamente, para fins acadêmicos e científicos, a reprodução total ou parcial desta dissertação, por processos fotocopiadores e outros meios eletrônicos.

Carolina Maia Silva

Silva, Carolina Maia

Investigação do histórico familial entre sujeitos com diferentes tipos de fissuras orofaciais não sindrômicas / Carolina Maia Silva. - Bauru, 2019.

$101 \mathrm{p}$.; il.; $31 \mathrm{~cm}$.

Dissertação (Mestrado - Fissuras Orofaciais e Anomalias Relacionadas) - Hospital de Reabilitação de Anomalias Craniofaciais, Universidade de São Paulo.

Orientador: Lucimara Teixeira das Neves

Comitê de Ética HRAC-USP

Protocolo $\mathrm{n}^{0}: 3.360 .674$

Data: $31 / 05 / 2019$ 
FOLHA DE APROVAÇÃO

\section{Carolina Maia Silva}

Dissertação apresentada ao Hospital de Reabilitação de Anomalias Craniofaciais da Universidade de São Paulo para a obtenção do título de Mestre.

Área de Concentração: Fissuras Orofaciais e Anomalias Relacionada

Aprovado em:

Banca Examinadora

Prof. Dr.

Instituição

Prof. Dr.

Instituição

Prof. Dr.

Instituição

Prof.(a) Dr.(a)

Instituição (Orientador)

Prof.(a) Dr.(a)

Presidente da Comissão de Pós-Graduação do HRAC-USP

Data de depósito da dissertação junto à SPG: 



\section{DEDICATÓRIA}

Dedico esta dissertação primeiramente a Deus, por ser minha força e meu guia; por sua bondade e misericórdia infinita, que me deu sabedoria e forças para concluir mais esta etapa.

Aos meus amigos e familiares, que me acompanharam durante o percurso da realização deste trabalho; por me darem forças e por sempre me apoiarem. 



\section{AGRADECIMENTOS}

Gratidão à minha orientadora, Profa. Dra. Lucimara Teixeira das Neves, pessoa a qual eu admiro e tenho muito carinho, pelo seu exemplo humano e profissional. Muito obrigada por me acolher e depositar sua confiança em mim; pela paciência, dedicação e ensinamentos transmitidos durante essa jornada.

À minha família, em especial à minha mãe Eliane, aos meus avós Arlindo e Aparecida, aos meus irmãos Fernando e Kátia e ao meu noivo Gustavo, por todo amor e confiança depositados em mim; por me apoiarem em todos os momentos e circunstâncias.

Ao nosso grupo de pesquisa, pessoas que tive o privilégio de conviver durante esta etapa, o meu carinho e admiração, obrigada pela amizade que construímos e por tonarem essa jornada mais prazerosa e alegre. À bióloga Thaís Bernardes de Queiroz e à biomédica Maria Carolina de Moraes Pereira, às quais agradeço por toda ajuda e colaboração. Aos dentistas, José Francisco MateoCastillo, Aline Cristina da Silva Trevizan, Andréa Guedes Barreto Gonçales e Pollyana Pereira Teotônio dos Santos, obrigada por todo apoio e cumplicidade.

Ao Hospital de Reabilitação de Anomalias Craniofaciais da Universidade de São Paulo (HRAC - USP), é uma imensa honra me formar neste grande centro de estudo. Ao seu superintendente Prof. Dr. Carlos Ferreira dos Santos e ao Programa de Pós-Graduação, na pessoa de sua presidente, Profa. Dra. Ivy Kiemle Trindade Suedam, por me acolherem como aluna deste programa.

Um agradecimento especial aos funcionários do setor de Arquivo do HRACUSP, Sr. Dimas, Eduardo, Wallace, Sônia, Lúcia Andréia, José, Ana, Peterson, Cidinha, Willian e Luís, por me auxiliarem diariamente e por se colocarem sempre à disposição, a vocês serei sempre grata. Às funcionárias da Pós-Graduação do HRAC-USP: Maria José, Ana Regina, Lucy e Lavínia, obrigada por todo auxílio. Aos funcionários do Comitê de Ética em Seres Humanos do HRAC-USP, em especial Rose e Rafael. À Flávia Cintra pelo auxílio com as análises estatísticas. Por fim, a todos os funcionários do HRAC-USP, que participaram direta ou indiretamente da realização deste trabalho, o meu muito obrigada. 

Aos colegas, professores e funcionários do Departamento de Ciências Biológicas da Faculdade de Odontologia de Bauru (FOB - USP), do Laboratório de Farmacologia e Genética: que sem fazer menção especial, agradeço pela parceria e amizade ao longo da nossa trajetória na pós-graduação.

Aos meus colegas de mestrado, por todos os momentos e vivências compartilhadas. Especialmente: Mariana Mendes Silva, Laís Hollara Medeiros e Ana Carolina Medeiros.

Aos meus amigos pessoais, obrigada por me apoiarem sempre e por estarem ao meu lado me dando forças para continuar nesta jornada.

À Coordenação de Aperfeiçoamento de Pessoal de Nível Superior (CAPES) pelo apoio financeiro na concessão da bolsa de mestrado e pelo auxílio PROAP para minha participação no ECPCA 2019. 

"A vida me ensinou e está me ensinando a aproveitar o presente, como um presente que da vida recebi, e usá-lo como um diamante que eu mesmo tenha que lapidar Ihe dando forma da maneira que eu escolher."

Charles Chaplin 



\section{RESUMO}

Silva, CM. Investigação do histórico familial entre sujeitos com diferentes tipos de fissuras orofaciais não sindrômicas [dissertação]. Bauru: Hospital de Reabilitação de Anomalias Craniofaciais, Universidade de São Paulo; 2019.

As fissuras labiopalatinas (FL/P) são as anomalias craniofaciais congênitas mais prevalentes na população. Essa anomalia pode se apresentar na forma sindrômica, fazendo parte de um quadro mais amplo; ou pode ocorrer na forma não-sindrômica, onde o fenótipo ocorre de forma isolada. A fissura labiopalatina não sindrômica apresenta etiologia complexa e multifatorial, na qual ocorre uma inter-relação entre os fatores genéticos e ambientais. Considerando que o histórico familial é uma variável importante a ser destacada em condições que apresentam o componente genético em sua etiologia, como é o caso das fissuras labiopalatinas, acredita-se que investigar o perfil do histórico familial positivo seja importante para verificar se este apresenta a mesma distribuição em diferentes Subgrupos de tipos de FL/P. Objetivo: Investigar o histórico familial para as fissuras labiopalatinas entre sujeitos com diferentes tipos de fissuras labiopalatinas não sindrômicas. Nos casos de histórico familial positivo, descrever o grau de parentesco do familiar afetado em relação ao sujeito avaliado e verificar se existe um padrão quanto ao tipo de fissura presente nos parentes afetados, verificando se existe alguma relação entre o tipo de fissura pré-existente naquela família e a severidade da anomalia no probando analisado. E ainda, confirmar a hipótese de que as fissuras mais complexas, transforame incisivo (unilateral e bilateral), apresentam frequência superior de histórico familial positivo quando comparadas as frequências entre sujeitos com fissura pré e pós-forame incisivo. Material e métodos: Para seleção da amostra, foi solicitado ao Centro de Processamento dos Dados (CPD - HRAC), uma listagem com todos os indivíduos com diagnóstico confirmado de fissura labiopalatina não sindrômica, matriculados no Hospital de Reabilitação de Anomalias Craniofaciais da Universidade de São Paulo (HRAC - USP). Foram selecionados, de forma aleatória, 335 sujeitos em cada um dos 8 Subgrupos de tipos de fissuras labiopalatinas, totalizando uma amostra com 2680 sujeitos. Foram coletadas, dos prontuários médicos, informações referentes ao tipo de fissura do sujeito e dados acerca do histórico familial positivo para essa anomalia na família. Os dados foram tabulados e 

avaliados por meio de estatística descritiva e comparativa, para a qual foi utilizado o teste Qui-quadrado $\left(\mathrm{X}^{2}\right)$, adotando $\mathrm{p}<0,05$ como estatisticamente significativo. Resultados: Na casuística geral, o histórico familial positivo foi encontrado em $31 \%$ dos casos. A maior prevalência foi encontrada no Grupo II (fissura transforame incisivo, unilateral e bilateral), com $36 \%$ dos casos. Nas comparações entre os 3 grupos principais, foram encontradas diferenças estatisticamente significativas quando o Grupo I (fissura pré-forame incisivo) foi comparado ao Grupo III (fissura pós-forame incisivo) e, também, quando o Grupo II (fissura transforame incisivo) foi comparado ao Grupo III (fissura pós-forame incisivo) ( $p<0,001)$. Não foram encontradas diferenças estatisticamente significativas nas comparações entre os Subgrupos, quando comparados entre si. Da amostra total de sujeitos com histórico familial positivo, $78 \%$ apresentavam apenas mais um caso na família. Na análise dos 3 grupos principais e, na análise dos 8 Subgrupos, foi constatado que em pelo menos $70 \%$ deles o histórico familial era único, ou seja, havia apenas mais um parente acometido pela fissura. $\mathrm{Na}$ amostra total, o grau de parentesco mais frequente foi parentesco distante $(n=456)$, seguido por pai e mãe $(n=107)$. Quando analisado o grau de parentesco considerando somente os parentes de $1^{\circ}, 2^{\circ}$ e $3^{\circ}$ grau, constatou-se que os parentes de $1^{\circ}$ grau haviam sido os mais acometidos (49\%). Na análise dos 3 grupos principais e, também, na análise individual dos 8 diferentes Subgrupos, o parentesco de $1^{\circ} \mathrm{grau}$ foi o mais frequente. De forma geral, o tipo de fissura mais encontrada, nos parentes de sujeitos com FL/P, foi a fissura transforame incisivo (43,8\%). Nos Grupos principais I e II, o tipo de fissura mais encontrada no parente afetado, foi a transforame incisivo e, no Grupo III, o tipo de fissura mais encontrada foi a pós-forame incisivo. Conclusão: A prevalência de histórico familial positivo na amostra foi de $31 \%$. Os sujeitos com fissura transforame incisivo (unilateral + bilateral), foram os que apresentaram as maiores taxas de histórico familial positivo. Nos casos com histórico familial positivo, os sujeitos apresentaram, na maior parte das vezes, apenas um outro parente afetado. O grau de parentesco mais encontrado foi parentes de $1^{\circ}$ grau. Nas fissuras transforame incisivo e nas pós-forame incisivo foi constatado que existe um padrão de ocorrência do tipo de fissura na família.

Descritores: Fissura labial. Fissura palatina. Etiologia. 



\section{ABSTRACT \\ Silva, CM. Investigation of Family history among subjects with different types of non-syndromic orofacial clefts[dissertation]. Bauru: Hospital de Reabilitação de Anomalias Craniofaciais, Universidade de São Paulo; 2018}

The cleft lip and/or palate (CL/P) are the most common congenital craniofacial anomalies seen in the population. This anomaly can be syndromic, being part of a wider context; or can occur in a non-syndromic form, where the phenotype occurs in an isolated form. The non-syndromic orofacial cleft presents a complex and multifactorial etiology, wherein there is an inter-relation among genetic and environmental factors. Taking into consideration that the family history is an import variable to be highlighted in conditions that present the genetic component in its etiology, as it is the case with the cleft lip and palate, it is believed that investigating the profile of positive family history is important to verify if it presents the same distribution in different (CL/P) subgroups types. Objective: To investigate the family history of orofacial cleft among subjects with different types of non-syndromic cleft lip and/or palate. In positive cases of family history, to describe the degree of kinship of the affected relatives in relation to the evaluated subject and verify if there is a pattern regarding the type of cleft present in the affected relatives, checking if there is any relationship between the type of pre-existing cleft in that family and the severity of the anomaly in the evaluated subject. Furthermore, to confirm the hypothesis that the more complex clefts, cleft lip and palate (unilateral or bilateral), present higher frequency of positive family history when compared with the frequency among subjects with isolated cleft lip and isolated cleft palate. Material and methods: For the sample selection, a list was requested to the Data Processing Center (DPCHRAC) containing all individuals with a confirmed diagnosis of non-syndromic cleft lip and/or palate enrolled at the Hospital for Rehabilitation of Craniofacial Cleft, University of Sao Paulo (HRAC-USP). A total of 335 subjects were randomly selected from each of the 8 Subgroups of orofacial cleft types, totaling a sample of 2680. Information on the subject's clef type and data on positive family history for this anomaly were collected from the medical records. The data were tabulated and evaluated using descriptive and comparative statistics, for which the Chi-square $\left(X^{2}\right)$ 

was used, adopting $\mathrm{p}<0,05$ as statistically significant. Results: In the general sample, the positive family history was found in $31 \%$ of the cases. In the general sample, the positive family history was found in $31 \%$ of the cases. The highest prevalence was found in the group II (cleft lip and palate, unilateral and bilateral), with $36 \%$ of the cases. In the comparison between the 3 main groups, statistically significant differences were found when the group I (isolated cleft lip) was compared to the group III (isolated cleft palate) and also when the group II (cleft lip and palate) was compared to the group III (isolated cleft palate) $(p<0,001)$. Statistically significant differences were not found in comparisons between Subgroups when compared to each other. Of the total sample of subjects with a positive family history, $78 \%$ had only one more case in the family. In the analysis of the 3 main groups and in the analysis of the 8 Subgroups, they presented at least $70 \%$ of positive family history in a single relative affected by the anomaly. In the total sample, the most frequent degree of kinship was distant kinship ( $n=456)$, followed by father and mother $(n=107)$. When analyzing the degree of kinship considering only the $1^{\text {st }}, 2^{\text {nd }}$ and $3^{\text {rd }}$ degree relatives, it was found that the first-degree relatives were the most affected $(49 \%)$. In the analysis of the 3 main groups and also in the individual analysis of the 8 different Subgroups, the first-degree kinship was the most frequent. In general, the most frequent type of cleft found in relatives of subjects with CL/P was the cleft lip and palate. In the main groups I and II, the most frequently found type of cleft in the affected relative was cleft lip and palate, in the group II, and in the group III, the type of cleft was isolated cleft palate. Conclusion: The prevalence of positive family history in this sample was $31 \%$. The subjects with cleft lip and palate (unilateral + bilateral) presented the highest rates of positive family history. In the cases with positive family history, the subjects presented, in most instances, only one more affected relative. The most frequent degree of kinship was first degree relatives. In the cleft lip and palate and isolated cleft palate, it was found that there is a pattern of occurrence of cleft in the family.

Keywords: Cleft lip. Cleft palate. Etiology. 



\section{LISTA DE ILUSTRAÇÕES}

Figura 1 - Esquema ilustrando os diferentes tipos de fissuras de acordo com a Classificação de Spina et al. (1972), modificada por Silva Filho et al. (1992). Em A e B: fissura pré-forame incisivo unilateral completa; em $C$ e D: fissura transforame incisivo unilateral; em $E$ e F: fissura transforame incisivo bilateral; em $\mathrm{H}$ : fissura pós-forame incisivo incompleta; e, em $\mathrm{H}$ : fissura pós-forame incisivo completa.

Figura 2 - Cirurgias Plásticas Primária: A e B: pré e pós-operatório da queiloplastia (reparação cirúrgica do lábio); C e D: pré e pósoperatório da palatoplastia (correção cirúrgica do palato).

Figura 3 - Método de Classificação do Grau de Parentesco sugerido por Nussbaum, Mclnnes e Willard (2016).

Figura 4 - Mapa brasileiro dividido de acordo com as 5 regiões brasileiras, destacando as porcentagens de sujeitos com diferentes tipos de FL/P não sindrômica analisados no estudo, de acordo com a naturalidade.

Figura 5 - Distribuição quanto ao sexo dos sujeitos com histórico familial positivo para as fissuras labiopalatinas, distribuídos de acordo com os 8 diferentes Subgrupos.

Figura 6 - Quantidade total de sujeitos do Grupo I (fissura pré-forame incisivo) que relataram histórico familial positivo e negativo para as fissuras labiopalatinas

Figura 7 - Quantidade total de sujeitos do Grupo II (fissura transforame incisivo) que relataram histórico familial positivo e negativo para as fissuras labiopalatinas 

Figura 8 - Quantidade total de sujeitos do Grupo III (fissura pós-forame incisivo) que relataram histórico familial positivo e negativo para as fissuras labiopalatinas

Figura 9 - Distribuição do histórico familial positivo e negativo de acordo com os oito diferentes Subgrupos de sujeitos com FL/P não sindrômica.

Figura 10 - Número de familiares acometidos pelas fissuras labiopalatinas nos casos de sujeitos com histórico familial positivo, agrupados em único e múltiplo.

Figura 11 - Quantidade de parentes afetados pela anomalia, distribuídos de acordo com os 8 diferentes Subgrupos de fissuras labiopalatinas não sindrômica analisados

Figura 12 - Grau de parentesco do parente acometido pela FL/P distribuídos nos 3 grupos principais de probandos analisados.

Figura 13 - Distribuição do tipo de fissura encontrada nos parentes dos indivíduos estudados distribuídos de acordo com os 3 grupos principais. 



\section{LISTA DE TABELAS}

Tabela 1 - Agrupamento dos 8 diferentes Subgrupos de tipos de fissura labiopalatina não sindrômica, de acordo com a estrutura acometida, com base na classificação de Spina et al. (1972), modificada por Silva Filho et al. (1992).

Tabela 2 - Distribuição do grau de parentesco do parente afetado em relação ao sujeito avaliado, dividido em 9 diferentes categorias de grau de parentesco.

Tabela 3 - Número amostral e porcentagem de sujeitos analisados nos 8 diferentes grupos de fissura labiopalatina não sindrômica, distribuídos conforme o sexo.

Tabela 4 - Quantidade total de sujeitos que relataram histórico familial positivo ou negativo para fissuras labiopalatinas.

Tabela 5 - Naturalidade dos indivíduos com histórico familial positivo para a fissura labiopalatina não sindrômica.

Tabela 6 - Comparação entre o Grupo I (fissura pré-forame incisivo) com o Grupo II (fissura transforame incisivo), em relação ao histórico familial positivo.

Tabela 7 - Comparação entre o Grupo I (fissura pré-forame incisivo) com o Grupo III (fissura pós-forame incisivo), em relação ao histórico familial positivo.

Tabela 8 - Comparação entre o Grupo II (fissura transforame incisivo) com o Grupo III (fissura pós-forame incisivo), em relação ao histórico familial positivo. 

Tabela 9 - Comparação entre os Subgrupos I.a + I.c com os Subgrupos I.b + I.d, em relação ao histórico familial positivo.

Tabela 10 - Comparação entre o Subgrupo I.a com o Subgrupo I.c, em relação ao histórico familial positivo.

Tabela 11 - Comparação entre o Subgrupo I.b com o Subgrupo I.d, em relação ao histórico familial positivo.

Tabela 12 - Comparação entre o Subgrupo II.a com o Subgrupo Il.b, em relação ao histórico familial positivo.

Tabela 13 - Comparação entre o Subgrupo III.a com o Subgrupo III.b, em relação ao histórico familial positivo.

Tabela 14 - Número de familiares acometidos pela FL/P, de acordo com a frequência em que o evento ocorreu, agrupado nos três grupos principais e comparação entre os grupos em relação a quantidade de sujeitos acometidos em cada um deles.

Tabela 15 - Grau de parentesco dos parentes acometidos pelas fissuras labiopalatinas, nos casos de histórico familial positivo.

Tabela 16 - Grau de parentesco dos parentes acometidos pelas fissuras, distribuídos segundo a classificação e Nussbaum, Mclnnes e Willard (2016).

Tabela 17 - Grau de parentesco dos parentes dos sujeitos acometidos pelas fissuras, distribuídos de acordo com os 8 diferentes Subgrupos de fissuras labiopalatinas, segundo a classificação de Nussbaum, Mclnnes e Willard (2016). 

Tabela 18 - Tipo de fissura encontrada no familiar acometido pela anomalia, classificado de acordo com a classificação de Spina et al. (1972), modificada por Silva Filho et al. (1992).

Tabela 19 - Tipo de fissura encontrada nos parentes dos indivíduos com FL/PNS, distribuídos de acordo com os 8 Subgrupos, sendo o tipo de fissura do parente afetado classificado de acordo com Spina et al. (1972), modificada por Silva Filho et al. (1992). 



\section{LISTA DE ABREVIATURA E SIGLAS}

$\begin{array}{ll}\text { CAPES } & \text { Superior } \\ \text { CEP } & \text { Comitê de Ética em Pesquisa em Humanos } \\ \text { CPD } & \text { Centro de Processamento de Dados } \\ \text { FL } & \text { Fissura de Lábio } \\ \text { FL/P } & \text { Fissura Labiopalatina } \\ \text { FL/PNS } & \text { Fissura Labiopalatina Não Sindrômica } \\ \text { FLP } & \text { Fissura de Lábio e Palato } \\ \text { FOB } & \text { Faculdade de Odontologia de Bauru } \\ \text { FP } & \text { Fissura de Palato } \\ \text { HRAC } & \text { Hospital de Reabilitação de Anomalias Craniofaciais } \\ \text { PROAP } & \text { Programa de Apoio à Pós-Graduação } \\ \text { USP } & \text { Universidade de São Paulo }\end{array}$

Coordenação de Aperfeiçoamento de Pessoal de Nível Superior 

1 INTRODUÇÃO

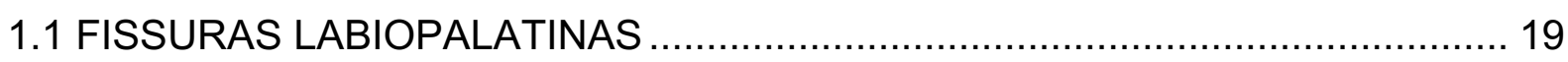

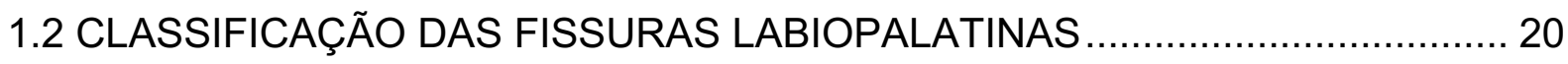

1.3 EPIDEMIOLOGIA DAS FISSURAS LABIOPALATINAS .................................. 21

1.4 ETIOLOGIA DAS FISSURAS LABIOPALATINAS ........................................ 23

2 OBJETIVO

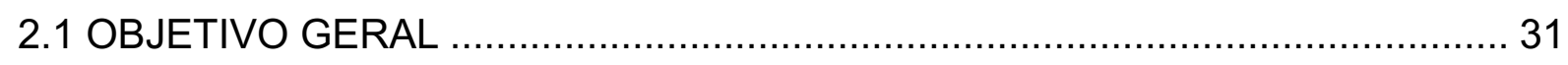

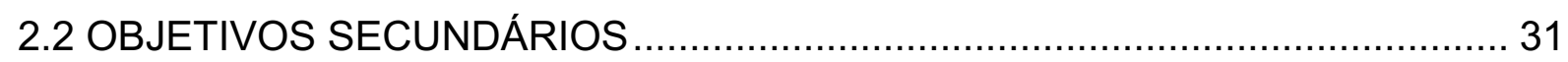

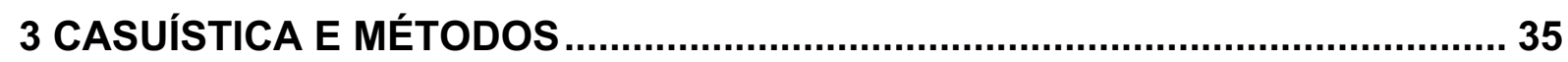

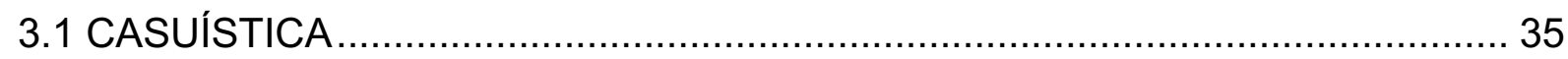

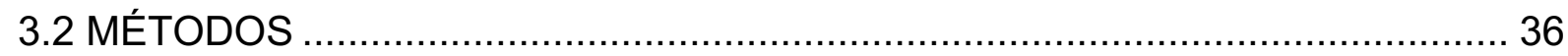

3.2.1 Levantamento do Histórico Familial e Identificação do Sujeito ................. 37

3.2.2 - Caracterização de Acordo com o Número de Parentes Afetados .......... 39

3.2.3 - Categorização de Acordo com o Grau de Parentesco do Familiar

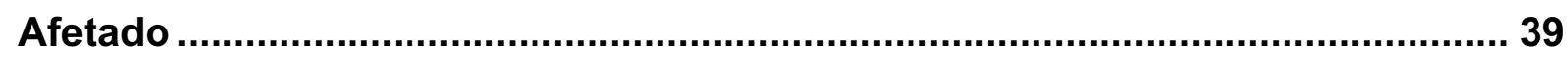

3.2.4 - Tipo de Fissura no Parente Afetado ...................................................... 41

4 RESULTADOS

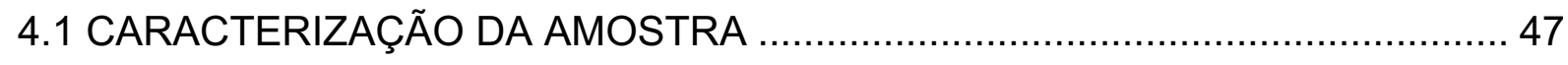

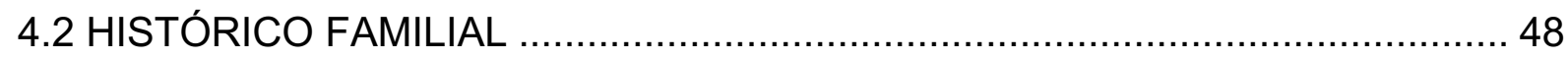

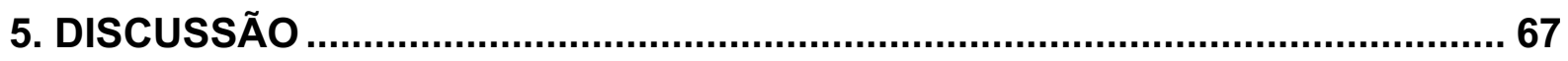

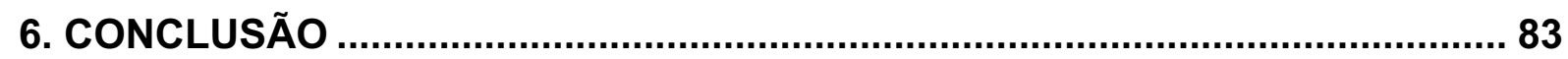

REFERÊNCIAS

ANEXO 



\section{INTRODUÇÃO E REVISÃO DA LITERATURA}





\section{INTRODUÇÃO}

\subsection{FISSURAS LABIOPALATINAS}

As fissuras de lábio e/ou palato (FL/P) são as anomalias craniofaciais congênitas mais comuns que acometem o ser humano (RODRIGUES et al.,2009; FREITAS et al., 2012; ABDOLLAHI-FAKHIM et al., 2015).

Historicamente, no que diz respeito aos estudos acerca das FL/P, estes se iniciaram em 1833 por um russo chamado Frobelius que encontrou, em uma pesquisa com 180 mil crianças, 118 casos de fissura labiopalatina (MENEGOTTO; SALZANO, 1991).

Essa anomalia acontece entre o período embrionário e início o período fetal, aproximadamente entre a $4^{a}$ e $12^{\circ}$ semana de vida intrauterina. Se houver, durante esse período, alguma interferência durante o desenvolvimento craniofacial, resultando em alterações no decorrer da migração, diferenciação e apoptose celular, poderá ocorrer uma falha no desenvolvimento facial ou palatino embrionário, resultando em uma anomalia estrutural facial, a fissura de lábio e/ou palato (LESLIE; MARAZITA 2013; FREITAS et al., 2012; MEIRA, 2014).

Do ponto de vista embriológico, a formação do lábio e do palato compreende um processo complexo e dinâmico. A formação do lábio superior se inicia por volta da $4^{a}$ semana de vida intrauterina e ao final da $6^{a}$ semana de desenvolvimento, a fusão dos processos nasais mediais entre si, concomitantemente aos processos maxilares lateralmente, leva à formação do lábio superior. Foi levantada a hipótese de que durante essa fase, o processo nasal lateral tem um pico de divisão celular, tornando-o suscetível a ação de agentes teratogênicos e qualquer distúrbio, nessa etapa, pode levar à falha no mecanismo de coalescência dos processos, podendo resultar na fissura de lábio, a qual pode atingir o alvéolo e palato primário (YU et al., 2009; AHMED; BUI; TAIOLI, 2017).

O desenvolvimento do palato se inicia durante a $6^{a}$ semana da embriogênese quando, no interior da boca primitiva, os processos palatinos começam a se 
desenvolver no sentido medial. $\mathrm{O}$ desenvolvimento se completa até por volta da $12^{\mathrm{a}}$ semana de vida intrauterina, quando na linha média os processos se fundem entre si, unindo-se também ao palato primário e ao septo nasal em desenvolvimento. A partir deste momento, as cavidades oral e nasal estão separadas, o que permite que a mastigação e a respiração ocorram ao mesmo tempo. Falhas durante esse processo podem levar à ocorrência da fissura de palato (TRINDADE; SILVA FILHO, 2007; YU et al., 2009; AHMED; BUI; TAIOLI, 2017).

\subsection{CLASSIFICAÇÃO DAS FISSURAS LABIOPALATINAS}

As fissuras de lábio e/ou palato representam um grupo heterogêneo de desordens que acometem a face e a cavidade oral (FREITAS et al., 2012). Diversos esquemas de classificação são utilizados para descrever as FL/P e estes podem basear-se na descrição anatômica, como a classificação de Tessier; na descrição morfogênica e clínica, como a classificação de van der Meulen; ou, ainda, se basear apenas no desenvolvimento embriológico, como a classificação de Spina modificada por Silva Filho (SPINA et al., 1972; TESSIER 1976; VAN DER MEULEN et al., 1983; SILVA FILHO et al., 1992).

Uma das classificações utilizadas no Brasil, também usada no Hospital de Reabilitação de Anomalias Craniofaciais da Universidade de São Paulo (HRAC USP), se baseia na descrição anatômica da anomalia. Esta classificação foi proposta por Spina et al. (1972), modificada por Silva Filho et al. (1992) e nela os diferentes tipos de fissuras são divididos em quatro grupos, os grupos de I a III levam em consideração o forame incisivo, como ponto anatômico de referência, pois esse é o vestígio embriológico que separa o palato primário do palato secundário. Assim, os grupos são classificados em: Grupo I - fissura pré-forame incisivo (Fissura de Lábio - FL); Grupo II - fissura transforame incisivo (Fissura de Lábio e Palato FLP); Grupo III - fissura pós-forame incisivo (Fissura de Palato - FP); e, Grupo IV fissuras raras da face (Figura 1). Os grupos I e II também podem ser classificados em unilateral, bilateral ou mediana (AHMED; BUI; TAIOLI, 2017). 

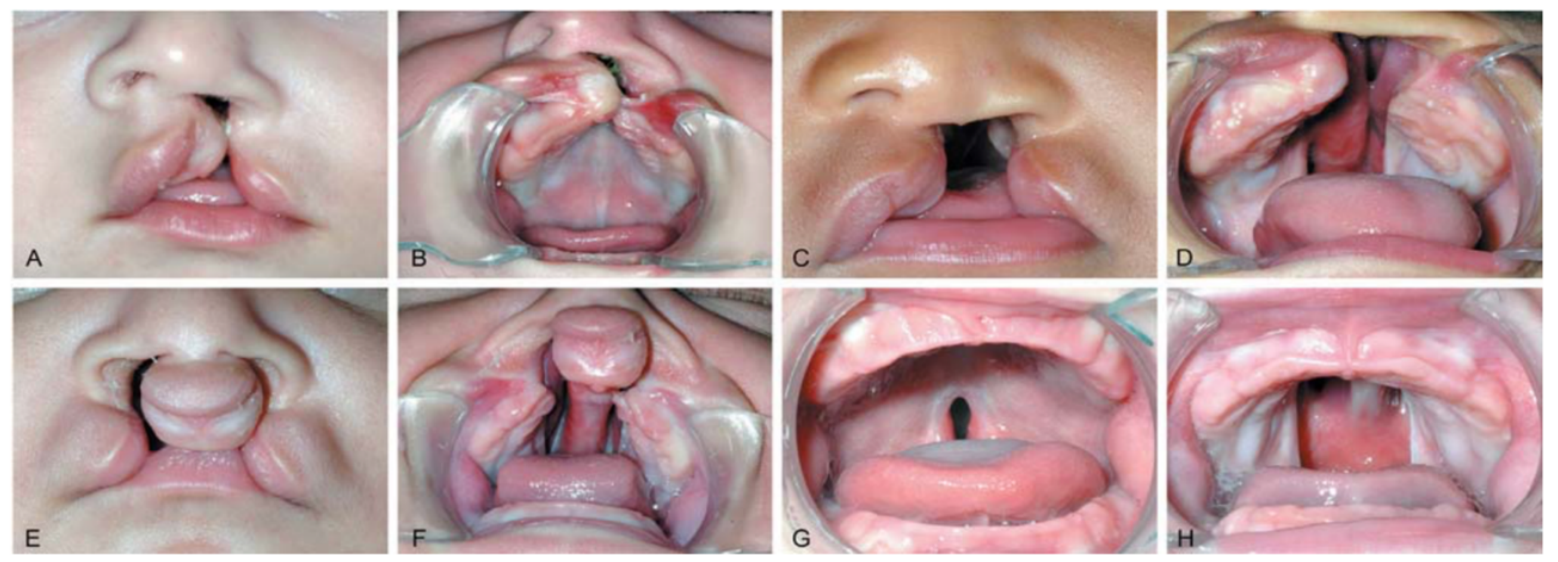

Fonte: Freitas et al., 2012.

Figura 1 - Esquema ilustrando os diferentes tipos de fissuras de acordo com a Classificação de Spina et al. (1972), modificada por Silva Filho et al. (1992). Em A e B: fissura préforame incisivo unilateral completa; em $\mathrm{C}$ e D: fissura transforame incisivo unilateral; em E e F: fissura transforame incisivo bilateral; em $\mathrm{H}$ : fissura pós-forame incisivo incompleta; e, em H: fissura pós-forame incisivo completa.

\subsection{EPIDEMIOLOGIA DAS FISSURAS LABIOPALATINAS}

Inúmeros estudos epidemiológicos sobre a incidência e a prevalência das fissuras labiopalatinas foram realizados em diversos países. Segundo Freitas e colaboradores (2012) a prevalência das fissuras orofaciais varia de acordo com a etnia e fatores socioeconômicos. De forma geral, para a população caucasiana e americana, as fissuras labiopalatinas têm uma prevalência de 1 em cada 700 nascidos vivos (MANGOLD et al., 2010; MARTELLI et al., 2012). É relatado na literatura uma maior prevalência em japoneses, com 2,1 casos a cada 1000 nascimentos, e em chineses, 1,7 casos a cada 1000 nascimentos. Em contraste, essa prevalência é menor na população negra, sendo encontrado 0,3 caso a cada 1000 nascimentos (GORLIN; COHEN JÚNIOR; LEVIN, 1990; FREITAS et al., 2012; FAN et al., 2018). Especificamente no Brasil, a ocorrência das fissuras labiopalatinas gira em torno de 1 para cada 650 nascidos vivos (TRINDADE; SILVA FILHO, 2007; FREITAS et al., 2012).

Estudos epidemiológicos demonstraram que a fissura transforame incisivo é mais comum entre indivíduos do sexo masculino, enquanto a fissura pós-forame incisivo é mais comum em sujeitos do sexo feminino. Além disso, o tipo de fissura 
mais frequentemente encontrado é a transforame incisivo unilateral esquerda (DI NINNO et al., 2011; FREITAS et al., 2012).

Segundo a literatura, os indivíduos com FL/P podem apresentar maior mortalidade devido a complicações neonatais, necessitando de acompanhamento multidisciplinar precoce, e este, quando não ocorre, pode ser devastador, principalmente em países nos quais o acesso a cuidados médicos é limitado (KANG; NARAYANAN; KELSALL, 2012; MEIRA, 2014). Esses sujeitos podem apresentar alterações estéticas e funcionais, como as variações fonéticas e mastigatórias, ou mesmo cognitivas. Além disso, podem apresentar dificuldades na realização da higiene oral, atividades sociais e atividades diárias, como se comunicar e mostrar os dentes ao sorrir (SILVA et al., 2018). Por estas razões, esses indivíduos são acompanhados, durante vários anos, por uma equipe multiprofissional a qual envolve profissionais de diversas áreas, como, cirurgiões dentistas, cirurgiões plásticos, fonoaudiólogos, psicólogos, entre outros (FREITAS et al., 2012).

Durante o processo de reabilitação, os indivíduos com FL/P necessitam de diversas cirurgias craniofaciais e procedimentos odontológicos para a reabilitação. A primeira cirurgia plástica para a reabilitação, é a queiloplastia, realizada a partir dos 3 meses de idade para a reparação do lábio. Quando o palato apresenta fissura, por volta dos 12 meses de idade, é realizada a cirurgia para sua correção, chamada palatoplastia (Figura 2). Além desses procedimentos iniciais, ao longo do processo de reabilitação, os indivíduos são submetidos a cirurgias secundárias mediante indicação da equipe ou por demanda do próprio paciente, mais comumente com a finalidade de reabilitação da fala e estética (TRINDADE; SILVA FILHO, 2007; FREITAS et al., 2012). 


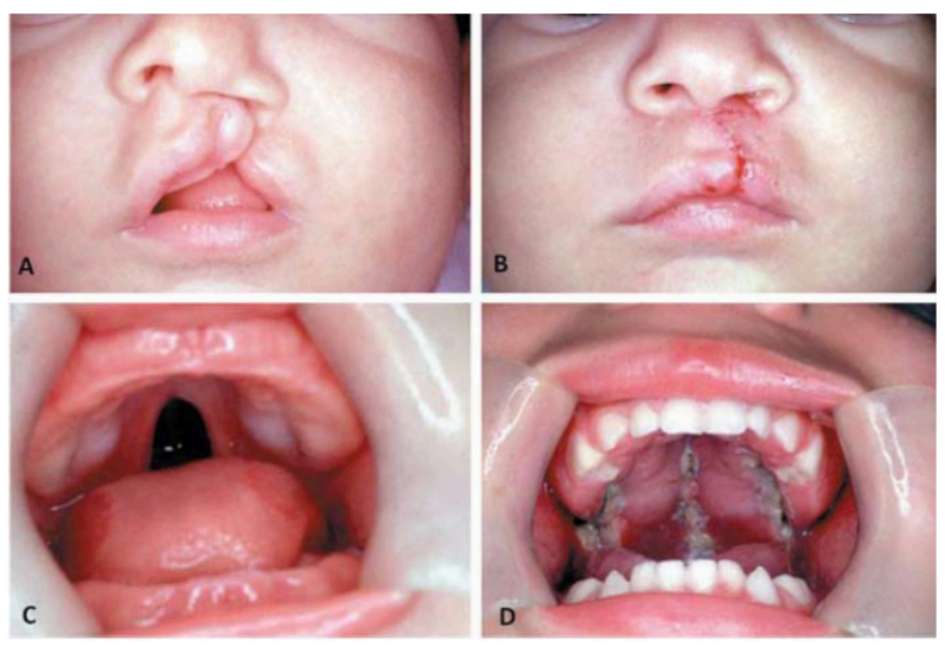

Fonte: Freitas et al., 2012

Figura 2 - Cirurgias Plásticas Primária: A e B: pré e pós-operatório da queiloplastia (reparação cirúrgica do lábio); C e D: pré e pós-operatório da palatoplastia (correção cirúrgica do palato).

\subsection{ETIOLOGIA DAS FISSURAS LABIOPALATINAS}

Para discutir sobra a etiologia dessa condição é importante definir que essa malformação pode se apresentar de duas formas distintas: como uma deformidade isolada, chamada de fissura não sindrômica ou associada a um quadro sindrômico, denominada fissura sindrômica (FREITAS et al., 2012; LESLIE; MARAZITA, 2013).

Cerca de $30 \%$ a $40 \%$ dos casos se enquadram nas fissuras sindrômicas, e existem mais de 300 síndromes descritas nas quais a fissura labiopalatina pode fazer parte do fenótipo, incluindo desordens cromossômicas e mendelianas (AQUINO et al., 2011; MENG et al., 2009; SCAPOLI et al., 2008). A síndrome de Van der Woude é a forma de fissura sindrômica mais comum, sendo diagnosticada em cerca de $2 \%$ de todos os casos de FL/P, apresentando prevalência de 1 a cada 34.000 nascidos vivos (LESLIE; MARAZITA, 2013). Outros exemplos de síndromes nos quais a FL/P é uma das características elencadas são, Síndrome de Treacher Collins e de Stickler (POSNICK; RUIZ, 2000; HIGUCHI et al., 2017).

Os $60 \%$ a $70 \%$ restantes se enquadram nos casos de fissuras labiopalatinas não sindrômicas (FL/PNS) e, nestes casos, a malformação não está associada a síndromes, ocorrendo de forma isolada (FREITAS et al., 2012). Essas fissuras isoladas apresentam mecanismo etiopatogênico definido como heterogêneo e 
complexo, determinando uma etiologia multifatorial, envolvendo uma inter-relação entre os fatores genéticos e ambientais, sendo que ambos os fatores desempenham papel de relevância na determinação dessa malformação (MOSSEY et al., 1999; ALDHORAE et al., 2014). Sabe-se que qualquer agente físico, químico ou biológico que tenha potencial de ação na diferenciação, migração e proliferação das células da crista neural, com subsequente envolvimento do mesênquima facial, durante o período de formação da face e do palato, representa um risco em potencial para a ocorrência da FL/P (FREITAS et al., 2012).

Entre os principais fatores ambientais relacionados a ocorrência das fissuras, são citados aqueles relacionados com questões comportamentais e hábitos maternos durante a gestação (AQUINO et al., 2011). O tabagismo materno durante a gestação tem sido associado ao aumento do risco de ocorrência de fissuras labiopalatinas (HONEIN et al., 2007). É sabido que o etilismo materno durante a gestação pode levar a ocorrência da Síndrome Alcoólica Fetal, porém o seu papel na ocorrência das fissuras labiopalatinas não sindrômicas ainda é incerto (MOSSEY et al., 2009). Outros fatores, incluindo deficiência nutricional de folato e completo B; uso de medicamentos, como anticonvulsivantes, antiepiléticos, antidepressivos e corticoides; exposição a agrotóxicos e pesticidas; e infecções durante a gestação, como toxoplasmose, também têm sido investigados quanto o seu papel na ocorrência das FL/P (MOSSEY et al., 2009; AQUINO et al., 2011; JAJJA et al., 2013; CAl et al., 2017).

Além do ambiente, os fatores genéticos também têm sido associados a essa malformação. A literatura revela que alguns genes candidatos, consanguinidade parental e histórico familial, podem estar envolvidos na etiologia das fissuras labiopalatinas não sindrômicas (TRINDADE; SILVA FILHO, 2007; BITTLES; BLACK, 2010; SETÓ-SALVIA; STANIER, 2014; SILVA et al., 2019).

Estudos apontam que mais de 350 genes já foram associados à ocorrência das fissuras labiopalatinas, de forma isolada ou em associação, podendo estes estar envolvidos com o processo de formação do lábio e do palato, ou, ainda, podendo interferir em alguma das etapas dos processos celulares e moleculares (VIEIRA, 2008). Alguns dos genes candidatos que já foram relacionados com a ocorrência da 
fissura labiopalatinas não sindrômica são: IRF6, NTN1, VAX1, LOXL3, SOX9, dentre outros (JIA et al., 2017; KHAN et al., 2018; ZHANG et al., 2018; JIANG et al., 2019; NEVES et al., 2019).

Em relação à consanguinidade parental, diversos estudos apontaram associação positiva desse fator com a ocorrência de fissura labiopalatinas não sindrômica (RAVICHANDRAN et al., 2012; SABBAGH et al., 2015; SILVA et al., 2019).

No que diz respeito à predisposição genética, um dos aspectos investigados é a recorrência familial para a malformação. As investigações a respeito desse assunto tiveram início em 1942 com o pesquisador Fogh-Andersen (1942 apud ALVAREZ; GUION-ALMEIDA; RICHIERI-COSTA, 2014). Esse autor analisou os fatores genéticos associados à fissura e a relação entre a fissura e a recorrência familial. Depois de observar um aumento na frequência dessa malformação em famílias de sujeitos com fissura, ele propôs que os fatores genéticos realmente contribuem para a fissura labiopalatina não sindrômica. A literatura relata que um embrião, que tenha relação de parentesco com um neonato afetado, tem entre $2 \%$ e $4 \%$ mais chances de desenvolver algum tipo de fissura labiopalatina (STEVENSON et al., 1993).

Especificamente a respeito do histórico familial para as fissuras, estudo realizado na Tanzânia, com 94 indivíduos com FL/P, encontrou 15\% dos casos (14 sujeitos) com histórico familial positivo para essa anomalia (BUYU et al., 2012). No lémen, Esmail e colaboradores (2014) avaliaram, durante o período de 6 anos, 1110 casos de indivíduos com fissuras orofaciais e encontraram que 199 sujeitos $(17,9 \%)$ apresentavam histórico familial positivo para fissuras orofaciais. Reiter e colaboradores (2015), na Alemanha, constataram que, dos 98 indivíduos com fissura avaliados na pesquisa, 38 (38,7\%) tinham algum parente de primeiro ou segundo grau com algum tipo de fissura de lábio e ou palato. Na China, um estudo conduzido por Li e colaboradores (2016), encontrou histórico positivo de fissuras orofaciais em $11,5 \%$ dos 113 casos analisados. Outra investigação chinesa encontrou uma taxa de $17,2 \%$ de histórico familial positivo para essa malformação craniofacial (NEOGI et al., 2017). Na Malásia, foi verificado que 50 indivíduos, dos 84 estudados, 
apresentavam histórico familial positivo para a FL/P (HAQUE; ALAM; KHAMIS, 2017).

Na América do Norte, uma investigação conduzida por Beaty e colaboradores (2001), a qual teve como objetivo verificar o número de parentes de primeiro grau também acometidos pela FL/P, apontou que 10 (11\%), dos 91 indivíduos com fissura de lábio com ou sem palato e $5(11,4 \%)$, dos 44 casos com fissura de palato isolado, apresentavam algum parente de $1^{\circ} \mathrm{grau}$ afetado por essa anomalia.

Apurando os dados da literatura de pesquisas realizadas na América do Sul, no que diz respeito ao histórico familial de sujeitos com fissuras labiopalatinas não sindrômicas, foi constatado, em um estudo conduzido Zapata e colaboradores (2010), na Colômbia, que o lado materno do probando afetado teve $21,6 \%$ de histórico familial positivo e o lado paterno $17,7 \%$.

Minerando informações a respeito do histórico familial para fissuras na população brasileira, em um estudo conduzido por Leite e Koifman (2009), no Rio de Janeiro, no qual foram avaliados 269 casos de sujeitos com fissuras de lábio e/ou palato, os autores encontraram 123 casos $(45,72 \%)$ com histórico familial positivo para essa anomalia congênita, deste modo, os autores afirmam existir uma forte associação entre as fissuras labiopalatinas e o histórico familial e, ainda, sugerem que esse tipo de detalhamento do histórico familial é de grande importância para a estimativa de predição de risco e aconselhamento genético. Nessa linha de investigação, Brito e colaboradores (2011) realizaram um estudo com 1022 sujeitos com fissura, em 5 diferentes cidades brasileiras (Santarém, Fortaleza, Barbalha, Maceió e Rio de Janeiro). Os autores constataram que, entre as regiões geográficas avaliadas, o histórico familial positivo para fissuras orofaciais, variou de $44 \%$ (Santarém) a 23\% (Maceió), tendo uma média de 32\% (329 indivíduos). No Nordeste brasileiro, uma investigação realizada por Fontes e colaboradores (2013), com 75 indivíduos, constatou que o histórico positivo para fissuras orofaciais estava presente $28 \%$ dos casos. No Sudeste do Brasil, estudos conduzidos por FalaganLotsch e colaboradores (2015) buscaram identificar qual era a taxa de histórico familial positivo, de acordo com o tipo de fissura do probando afetado. Os autores verificaram que, dos 39 casos de fissura de lábio, 8 deles $(21,1 \%)$ tinham histórico 
positivo de fissuras orofaciais na família; já nos casos de fissura de lábio e palato, dos 152 sujeitos avaliados, 38 (24,8\%) tinham histórico positivo; e, na fissura de palato isolada, dos 27 sujeitos analisados, 4 (14,8\%) apresentavam algum parente com FL/P.

Outro estudo conduzido no Sudeste brasileiro, com 803 sujeitos com diferentes tipos de fissuras, constatou que 32,3\% dos indivíduos analisando relatavam a existência de pelo menos um outro indivíduo com fissura na família (SOUZA-FREITAS et al., 2004), sendo que a anomalia apresentada pelos familiares, era, principalmente, fissura de lábio e palato (33,9\%). Os autores relataram ainda, quanto ao grau de parentesco, que o maior percentual de casos de fissura tinha ocorrido em parentes distantes (59\%); seguido de parentes de segundo grau $(20,1 \%)$; irmãos $(13,5 \%)$; mãe $(4,2 \%)$; e, pai $(3 \%)$. Os autores indicam que esses achados sustentam o componente hereditário na ocorrência das fissuras.

Ainda no Sudeste brasileiro, um outro estudo avaliou 356 sujeitos com fissura de lábio e/ou palato e constatou que 73 sujeitos (22\%) apresentavam histórico positivo para a fissura na família (ALVAREZ; GUION-ALMEIDA; RICHIERI-COSTA, 2014). Um estudo recente, realizado no Sudeste brasileiro, analisou o histórico familial para fissuras em sujeitos com fissura de palato isolada. Para tanto, foram avaliados 144 casos de sujeitos com fissura de palato isolada não sindrômica, sendo constatado que, deste total, $28,47 \%$ dos sujeitos tinham histórico positivo para diversos tipos de fissuras labiopalatinas na família (GARBIERI, 2016).

Analisando os estudos publicados até o momento é possível inferir que o histórico familial positivo para a fissura é um forte componente a ser considerado na predição do risco potencial de novos casos na família e, por isso, um importante fator a ser estudado. A partir da revisão de literatura apresentada é possível constatar que muitas pesquisas internacionais e nacionais investigaram o percentual de histórico familial positivo para as fissuras labiopalatinas no geral, independentemente do tipo de fissura do probando avaliado ou, ainda, agruparam diferentes tipos de fissura em um só grupo geral, dificultando estabelecer se existe ou não um padrão nos casos com histórico positivo, para os diferentes tipos de fissuras. E, assim, a maioria desses trabalhos não estabeleceu percentuais de 
histórico familial positivo para os diferentes tipos de fissuras separadamente. Além disso, as populações estudadas, em estudos anteriores, apresentavam casuísticas menores e, ainda, a maioria deles não apresenta dados sobre o grau de parentesco e o tipo de fissura do parente afetado, dificultando estabelecer se existe um padrão ou alguma relação entre os tipos de fissuras presentes nos familiares que antecederam os casos estudados e o probando em questão.

Por essas razões, o objetivo deste estudo foi levantar a frequência e o padrão do histórico familial para as fissuras (grau de parentesco e tipo de fissura do parente afetado) entre sujeitos com diferentes tipos de fissuras labiopalatinas não sindrômicas, matriculados no Hospital de Reabilitação de Anomalias Craniofaciais da Universidade de São Paulo (HRAC - USP), colaborando para a construção mais abrangente do conhecimento em relação a essa anomalia, com relação aos fatores familiais associados a sua ocorrência, possibilitando uma abordagem de orientação adequada para as famílias acometidas pela malformação, fundamentada em predição de risco. Além disso, buscamos confirmar a hipótese de que as fissuras mais complexas, no caso as transforame incisivo (unilateral e bilateral), apresentam frequência superior de histórico familial positivo para a anomalia quando comparadas as frequências entre sujeitos com fissura de lábio isolada ou fissura de palato isolada.

Ademais, entender o perfil de histórico familial da fissura labiopalatina contribui, significativamente, na definição de grupos de risco predispostos a malformação, população, essa, que deve ser alvo de atenção em políticas públicas de prevenção dos defeitos ao nascimento com impacto socioeconômico significativo. 
2 Objetivo 



\section{OBJETIVO}

\subsection{OBJETIVO GERAL}

Investigar o histórico familial para fissuras orofaciais entre sujeitos com diferentes tipos de fissura labiopalatina não sindrômica.

\subsection{OBJETIVOS SECUNDÁRIOS}

- Descrever, quando possível, de forma detalhada, nos casos com histórico familial positivo para fissuras orofaciais, o grau de parentesco do familiar afetado em relação ao sujeito avaliado.

- Elucidar se existe um padrão para os tipos de fissura encontrados nos familiares que antecederam os sujeitos estudados, com o intuito de verificar se há alguma relação entre os tipos de fissura pré-existentes naquela família e a severidade da anomalia no probando analisado.

- Confirmar a hipótese de que as fissuras mais complexas, no caso as transforame incisivo unilateral e bilateral, apresentam frequência superior de histórico familial positivo para a anomalia quando comparadas as frequências entre sujeitos com fissuras de lábio isolada e fissuras de palato isolada. 

3 Casuística e Métodos 



\section{CASUÍSTICA E MÉTODOS}

Este estudo observacional do tipo transversal retrospectivo de caráter exploratório foi realizado seguindo princípios Éticos e foi previamente aprovado pelo Comitê de Ética em Pesquisa do Hospital de Reabilitação de Anomalias Craniofaciais da Universidade de São Paulo (HRAC - USP), conforme o parecer consubstanciado número 3.360.674 (ANEXO A).

\subsection{CASUÍSTICA}

Inicialmente, para a seleção da amostra, foi solicitado um levantamento, junto ao Centro de Processamento de Dados (CPD) do HRAC - USP, de todos os sujeitos matriculados que apresentavam diagnóstico de qualquer tipo de fissura labiopalatina na forma não sindrômica, o qual forneceu uma lista com 42185 registros de sujeitos matriculados. Para a seleção dos casos que seriam incluídos no estudo, dividimos os diferentes tipos de FL/P não sindrômica em 8 diferentes Subgrupos estabelecidos para este estudo. Foram considerados elegíveis para este estudo, 38204 sujeitos matriculados no HRAC - USP, sendo estes distribuídos de acordo com o tipo de fissura. Os 3981 prontuários restantes correspondiam a outros tipos de fissura não incluídos neste estudo (como fissuras medianas) e/ou apresentavam, na descrição do tipo de fissura, alguma síndrome associada.

Para determinar o tamanho da amostra, foi realizado um cálculo amostral considerando uma frequência média de histórico familial positivo para os diferentes tipos de fissura em 32\%, conforme estudos brasileiros (SOUZA-FREITAS et al., 2004; LEITE; KOIFMAN, 2009; BRITO et al., 2011; FONTES et al., 2013; FALAGANLOTSCH et al., 2015), com intervalo de confiança de 95\% e erro amostral de 5\%. O tamanho estimado da amostra, após o cálculo amostral, foi de 335 sujeitos.

Dessa forma, foram selecionados aleatoriamente, através de sites específicos de sorteio e randomização, 335 prontuários médicos em cada um dos 8 Subgrupos (Subgrupo I.a - Fissura Pré-Forame Incisivo Unilateral Completa, Subgrupo I.b - 
Fissura Pré-Forame Incisivo Bilateral Completa, Subgrupo I.c - Fissura Pré-Forame Incisivo Unilateral Incompleta, Subgrupo I.d - Fissura Pré-Forame Incisivo Bilateral Incompleta, Subgrupo II.a - Fissura Transforame Incisivo Unilateral, Subgrupo II.b Fissura Transforame Incisivo Bilateral, Subgrupo III.a - Fissura Pós-Forame Incisivo Completa e Subgrupo III.b - Fissura Pós-Forame Incisivo Incompleta), totalizando uma amostra com 2680 sujeitos, dos quais foram coletadas todas as informações pertinentes.

Como critérios de confirmação e inclusão, para a seleção dos casos a serem analisados, foi considerado o diagnóstico confirmado do tipo de fissura de cada um dos Subgrupos, na forma não sindrômica. A fim de verificar se o sujeito se enquadrava nos critérios pré-estabelecidos e para que fosse confirmada a inclusão de cada caso, o diagnóstico descrito no prontuário arquivado do sujeito foi consultado. Foram excluídos do estudo os casos que apresentaram suspeita de síndrome ou malformação associada; aqueles que ainda não tinham o diagnóstico confirmado; sujeitos que não possuíam informações referentes ao histórico familial; indivíduos com informações do prontuário divergentes quando comparadas as do CPD - HRAC; e, também, aqueles que eram filhos adotivos.

Com base nos critérios de inclusão estabelecidos neste estudo, 92 sujeitos não foram considerados elegíveis e, por esta razão, foram excluídos da pesquisa. Constatamos que, dos sujeitos excluídos, 36 apresentavam tipo de fissura divergente quando comparada a informação do prontuário com a informação cadastrada no CPD - HRAC; 24 apresentavam Sequência de Pierre Robin; 11 não apresentavam informações, no prontuário, referentes ao histórico familial (positivo ou negativo); 8 apresentavam Síndrome de Van der Woude; 8 eram filhos adotivos; 2 indicavam suspeita de síndrome; 1 apresentava cromossomopatia; 1 tinha Síndrome de Apert; e, em 1 caso, o indivíduo apresentava Síndrome de Stickler.

\subsection{MÉTODOS}


Todas as informações coletadas de cada caso foram anotadas em uma planilha do programa Microsoft Office Excel 2019 (Microsoft Corp.), elaborada especialmente para essa finalidade.

\subsubsection{Levantamento do Histórico Familial e Identificação do Sujeito}

O histórico familial dos sujeitos foi classificado em positivo ou negativo, sendo considerado positivo quando encontrado, no prontuário do sujeito, informações referentes à ocorrência prévia de fissura na família do indivíduo analisado.

Para realização do levantamento do histórico familial e identificação do sujeito, foram coletadas as informações destes indivíduos contidas nos prontuários médicos arquivados, em diferentes segmentos.

No segmento de caso novo do prontuário, foram coletadas as informações referentes ao número de registro do sujeito no HRAC - USP, confirmação do tipo de fissura, data da matrícula no hospital e informações de identificação do indivíduo, como: idade, sexo, data de nascimento e naturalidade. Nos outros segmentos, referentes a consultas em outras áreas, foram coletadas as informações referentes à confirmação do diagnóstico do tipo de fissura do probando e os heredogramas, sendo por meio destes possível verificar o histórico familial para as fissuras labiopalatinas e identificar qual era o grau de parentesco do parente afetado em relação ao sujeito analisado. Além disso, quando disponível, eram coletadas as informações referentes ao tipo de fissura do familiar afetado.

Para a caracterização do tipo de fissura do probando avaliado e do(s) familiar(es) acometido(s) foi utilizada a classificação proposta por Spina et al. (1972), modificada por Silva Filho et al. (1992). Os 8 diferentes Subgrupos de tipos de fissura labiopalatina dos sujeitos investigados foram agrupados nos três grupos principais, levanto em consideração a região acometida (lábio isolado, palato isolado ou lábio e palato), forma de acometimento (completa ou incompleta) e lateralidade (direta ou esquerda, no caso das fissuras com envolvimento de lábio) (Tabela 1). 
Tabela 1 - Agrupamento dos 8 diferentes Subgrupos de tipos de fissura labiopalatina não sindrômica, de acordo com a estrutura acometida, com base na classificação de Spina et al. (1972), modificada por Silva Filho et al. (1992).

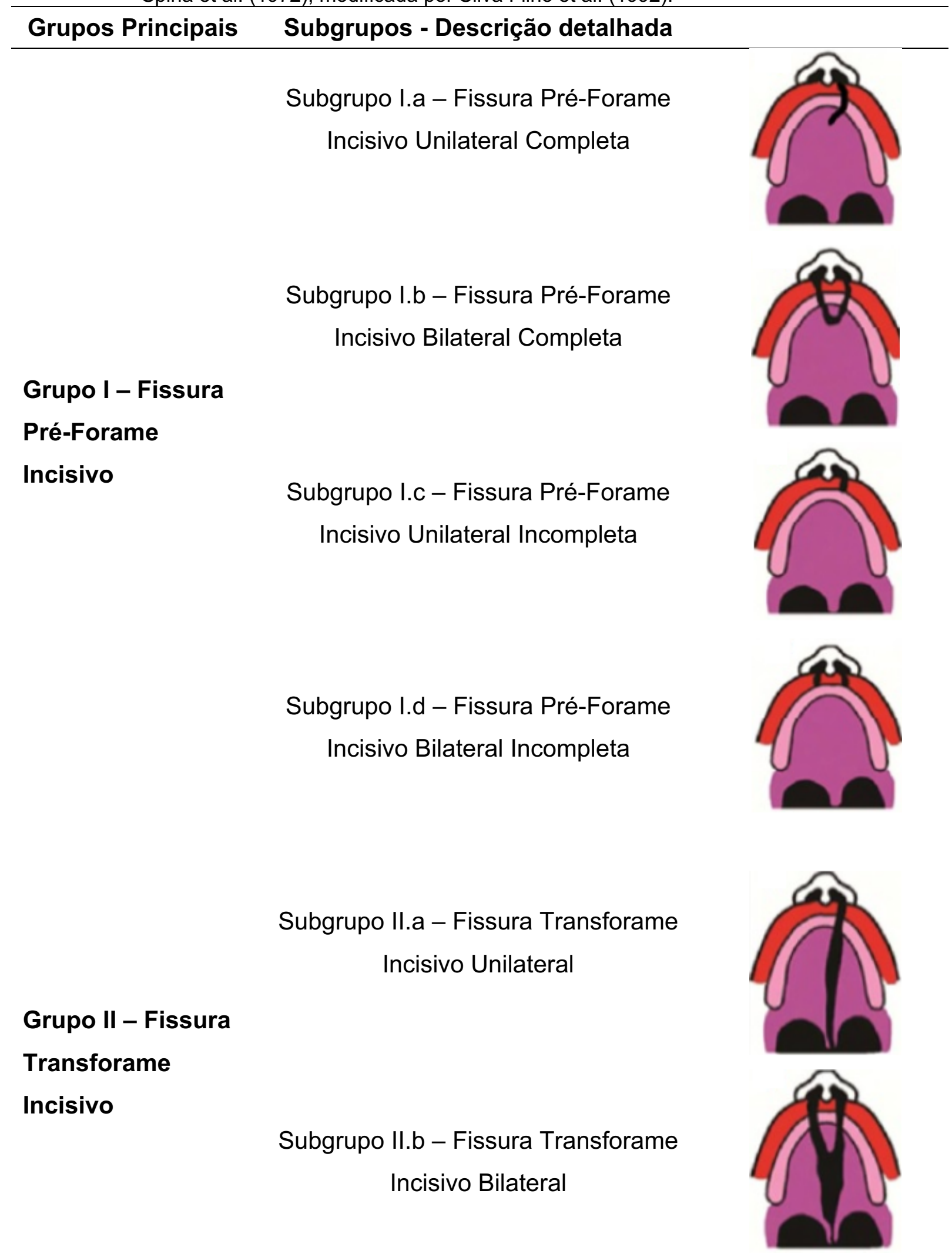




\section{Subgrupo III.a - Fissura Pós-Forame Incisivo Completa}

\section{Grupo III - Fissura}

\section{Pós-Forame}

Incisivo

$$
\begin{aligned}
& \text { Subgrupo III.b - Fissura Pós-Forame } \\
& \text { Incisivo Incompleta }
\end{aligned}
$$
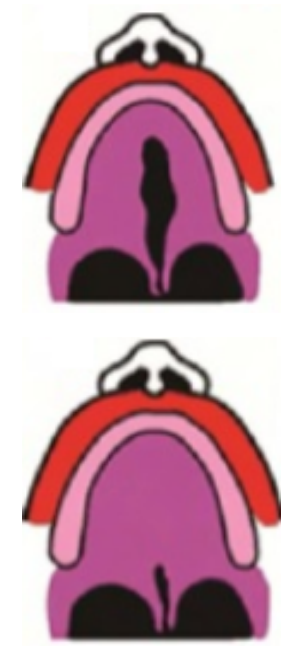

Fonte da imagem: Cymrot et al., 2010.

\subsection{2 - Caracterização de Acordo com o Número de Parentes Afetados}

Para a análise dos dados levantados, os indivíduos com histórico familial positivo para a anomalia foram agrupados de acordo com o número de repetições desse evento na família, sendo esse agrupamento de acordo com a seguinte categorização:

- Único: sujeitos que tiveram somente 1 parente com fissura de lábio e/ou palato.

- Múltiplo: sujeitos que tiveram 2 ou mais parentes com fissura de lábio e/ou palato.

\subsection{3 - Categorização de Acordo com o Grau de Parentesco do Familiar Afetado}

No que se refere a um dos objetivos secundários propostos neste trabalho, o qual tinha como intenção verificar qual o grau de parentesco do parente afetado em relação ao sujeito analisado, esta variável foi analisada inicialmente seguindo a categorização ampliada apresentada na Tabela 2 abaixo. 
Tabela 2 - Distribuição do grau de parentesco do parente afetado em relação ao sujeito avaliado, dividido em 9 diferentes categorias de grau de parentesco.

\section{Grau de Parentesco}

Pai e Mãe

Irmão e Irmã

Avô e Avó - materno e paterno

Tio e Tia - materno e paterno

Sobrinho e Sobrinha - materno e paterno

Meio-irmão e meia-irmã - materno e paterno

Primo e Prima de $1^{\circ} \mathrm{grau}$ - materno e paterno

Parentesco Distante - parente materno e paterno, como: primo e prima de $2^{\circ}, 3^{\circ} \mathrm{e}$ $4^{\circ}$ grau; tio avô e tia avó; bisavô e bisavó; tataravô e tataravó. Foram adicionados apenas os casos nos quais o prontuário médico continha o grau de parentesco do parente distante acometido por essa anomalia.

Sem informação precisa - quando não havia informação referente ao grau de parentesco indivíduo afetado. Ademais, também foram incluídos neste grupo, sujeitos com informações duvidosas e grau de parentesco muito distante, os quais não apresentavam informações confiáveis.

Posteriormente a essa primeira análise mais ampla do grau de parentesco, os casos foram agrupados e categorizados utilizando o Método de Classificação do Grau de parentesco sugerido por Nussbaum, Mclnnes e Willard (2016) da seguinte forma (Figura 3):

- Parentes de $1^{\circ} \mathrm{Grau}$ : pai e mãe; irmão e irmã.

- Parentes de $2^{\circ}$ Grau: avô e avó; tio e tia; meio irmão e meia irmã; sobrinho e sobrinha (materno e paterno).

- Parentes de $3^{\circ}$ Grau: primo e prima de $1^{\circ} \mathrm{grau}$ (materno e paterno). 
Figura 3 - Método de Classificação do Grau de Parentesco sugerido por Nussbaum, Mclnnes e Willard (2016).

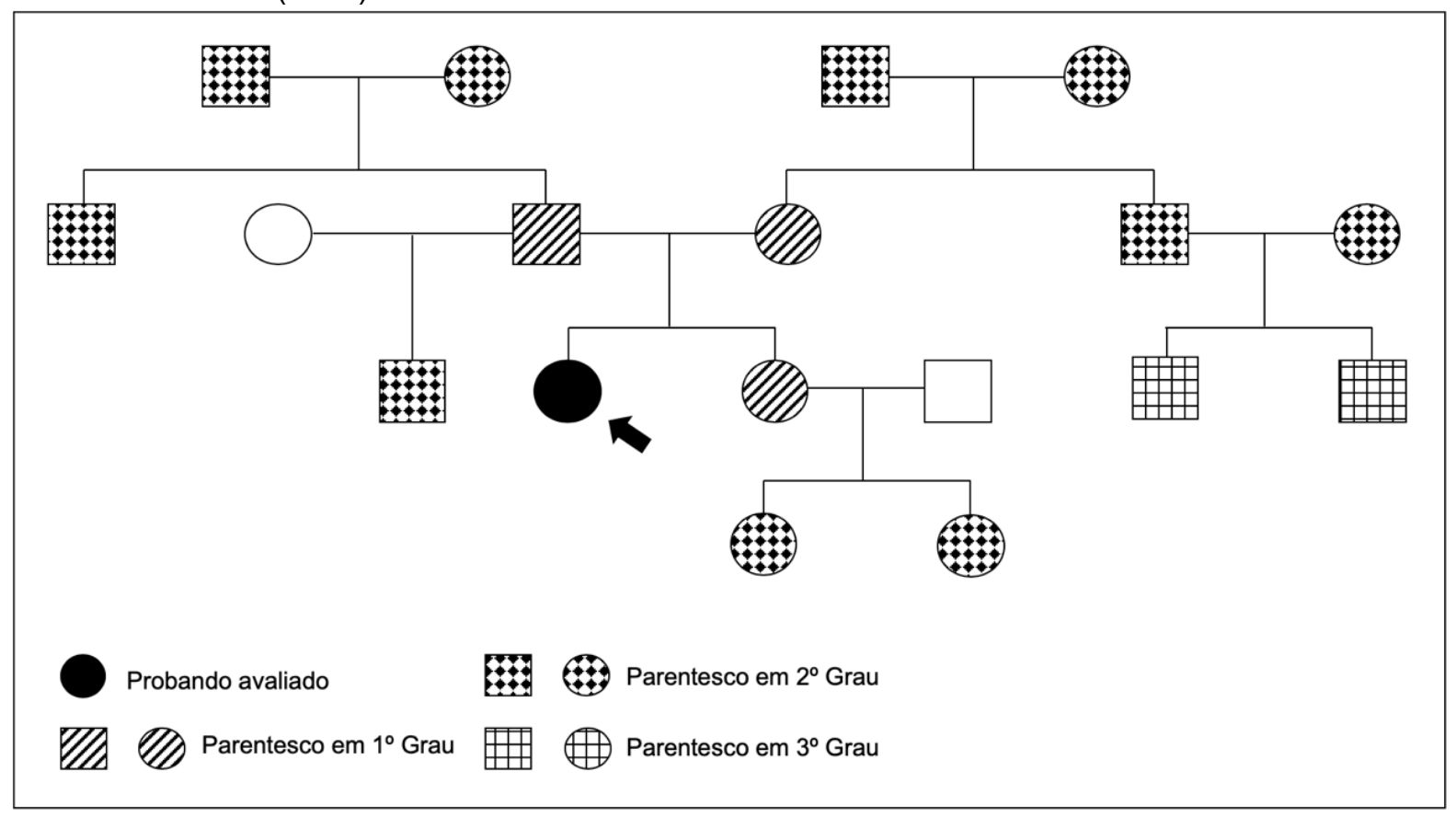

\subsection{4 - Tipo de Fissura no Parente Afetado}

Para a análise do tipo de fissura encontrada nos parentes afetados, estas foram classificadas de acordo com Spina et al. (1972), modificada por Silva Filho et al. (1992), sendo as fissuras descritas em um dos três grupos principais (Grupo I fissura pré-forame incisivo; Grupo II - fissura transforme incisivo; e, Grupo III fissura pós-forame incisivo). A escolha dessa classificação para essa análise específica do familiar afetado se deu devido ao fato deste estudo ter utilizado análise de dados secundários, minerando assim informações provenientes de prontuários médicos arquivados no HRAC - USP, os quais apresentavam, por vezes, falta de informação precisa no que diz respeito aos casos com histórico familial positivo.

Para reduzir o viés da informação referente ao tipo de fissura encontrada no parente do sujeito avaliado, foram excluídos os casos de parentesco distante e os casos sem informação precisa. 
Todas as informações obtidas dos sujeitos utilizadas neste estudo foram analisadas de forma anônima e os resultados foram tabulados de forma agregada.

Todos os dados minerados foram tabulados no programa Microsoft Office Excel 2019 (Microsoft Corp.), analisados por meio de estatística descritiva e apresentados em números absolutos (n) e suas respectivas frequências (\%). Para as diferentes análises comparativas entre os grupos foi utilizado o teste Quiquadrado $\left(\mathrm{X}^{2}\right)$, realizado no programa GraphPad Prism 12 (versão para Windows), adotando $p<0,05$ como estatisticamente significativo.

Em relação ao histórico familial positivo, na primeira análise comparativa, os 8 diferentes Subgrupos foram agrupados nos 3 grupos principais, de acordo com a classificação das fissuras labiopalatinas proposta por Spina et al. (1992), modificada por Silva Filho et al. (1992) (Grupo I - fissuras pré-forame incisivo; Grupo II - fissura transforame incisivo e Grupo III - fissura pós-forame incisivo). Desta forma, esses três grupos foram comparados aos pares (Grupo I com o Grupo II; Grupo I com o Grupo III; e, Grupo II com o Grupo III), utilizando o teste Qui-quadrado ( $\left.X^{2}\right)$.

Para verificar se havia diferença estatística, no que se refere ao histórico familial positivo, dentro de cada um dos 8 Subgrupos estudados, foi realizada a comparação dos Subgrupos entre si, respeitando o grupo principal de classificação. Assim, foram realizadas as seguintes comparações: entre os grupos de indivíduos com fissura pré-forame incisivo: Subgrupo I.a (fissura pré-forame incisivo unilateral completa) + Subgrupo I.c (fissura pré-forame incisivo unilateral incompleta) com o Subgrupo I.b (fissura pré-forame incisivo bilateral completa) + Subgrupo I.d (fissura pré-forame incisivo bilateral incompleta), entre o Subgrupo I.a (fissura pré-forame incisivo unilateral completa) com o Subgrupo I.c (fissura pré-forame incisivo unilateral incompleta) e entre o Subgrupo I.b (fissura pré-forame incisivo bilateral completa) com o Subgrupo I.d (fissura pré-forame incisivo bilateral incompleta); entre os indivíduos com fissura transforame incisivo: Subgrupo II.a (fissura transforame incisivo unilateral) com o Subgrupo II.b (fissura transforame incisivo bilateral); e entre os indivíduos com fissura pós-forame incisivo: Subgrupo III.a (fissura pós-forame incisivo completa) com o Subgrupo III.b (fissura pós-forame incisivo incompleta). 
Para verificar se havia diferença estatisticamente significativa, no que se refere ao número de parentes acometidos em cada uma das famílias dos indivíduos estudados (caracterizados em único ou múltiplo), foram realizadas as comparações entre os grupos principais, aos pares, entre si. Assim, foram realizadas, por meio do teste Qui-quadrado $\left(\mathrm{X}^{2}\right)$, as seguintes comparações: Grupo I com o Grupo II; Grupo I com o Grupo III; e, Grupo II com o Grupo III. 

4 RESULTADOS 



\section{RESULTADOS}

\subsection{CARACTERIZAÇÃO DA AMOSTRA}

A amostra foi composta por um total de 2680 indivíduos, 1448 do sexo masculino (54\%) e 1232 do sexo feminino (46\%). A Tabela 3 abaixo apresenta a distribuição de sujeitos do sexo masculino e feminino nos 8 Subgrupos analisados.

Tabela 3 - Número amostral e porcentagem de sujeitos analisados nos 8 diferentes grupos de fissura labiopalatina não sindrômica, distribuídos conforme o sexo.

\begin{tabular}{ccccc}
\hline Subgrupos & Masculino & Feminino & \% Masculino & \% Feminino \\
\hline Subgrupo I.a & 187 & 148 & $56 \%$ & $44 \%$ \\
Subgrupo I.b & 180 & 155 & $54 \%$ & $46 \%$ \\
Subgrupo I.c & 214 & 121 & $64 \%$ & $36 \%$ \\
Subgrupo I.d & 213 & 122 & $64 \%$ & $36 \%$ \\
Subgrupo II.a & 203 & 132 & $61 \%$ & $39 \%$ \\
Subgrupo II.b & 237 & 98 & $71 \%$ & $29 \%$ \\
Subgrupo III.a & 85 & 250 & $25 \%$ & $75 \%$ \\
Subgrupo III.b & 129 & 206 & $38 \%$ & $62 \%$ \\
\hline Total & 1448 & 1232 & $54 \%$ & $46 \%$ \\
\hline
\end{tabular}

Em relação à naturalidade total da amostra, quando brasileiros, verificamos que a maior parte, 1838, era proveniente do Sudeste; 292 do Centro-Oeste; 213 do Nordeste; 172 do Norte; e, 155 do Sul. Cinco sujeitos (0,2\%) eram não brasileiros (2 Paraguaios, 2 Japoneses e 1 Português) e 5 casos (0,2\%) não tinham informações sobre naturalidade dos sujeitos (Figura 4). 


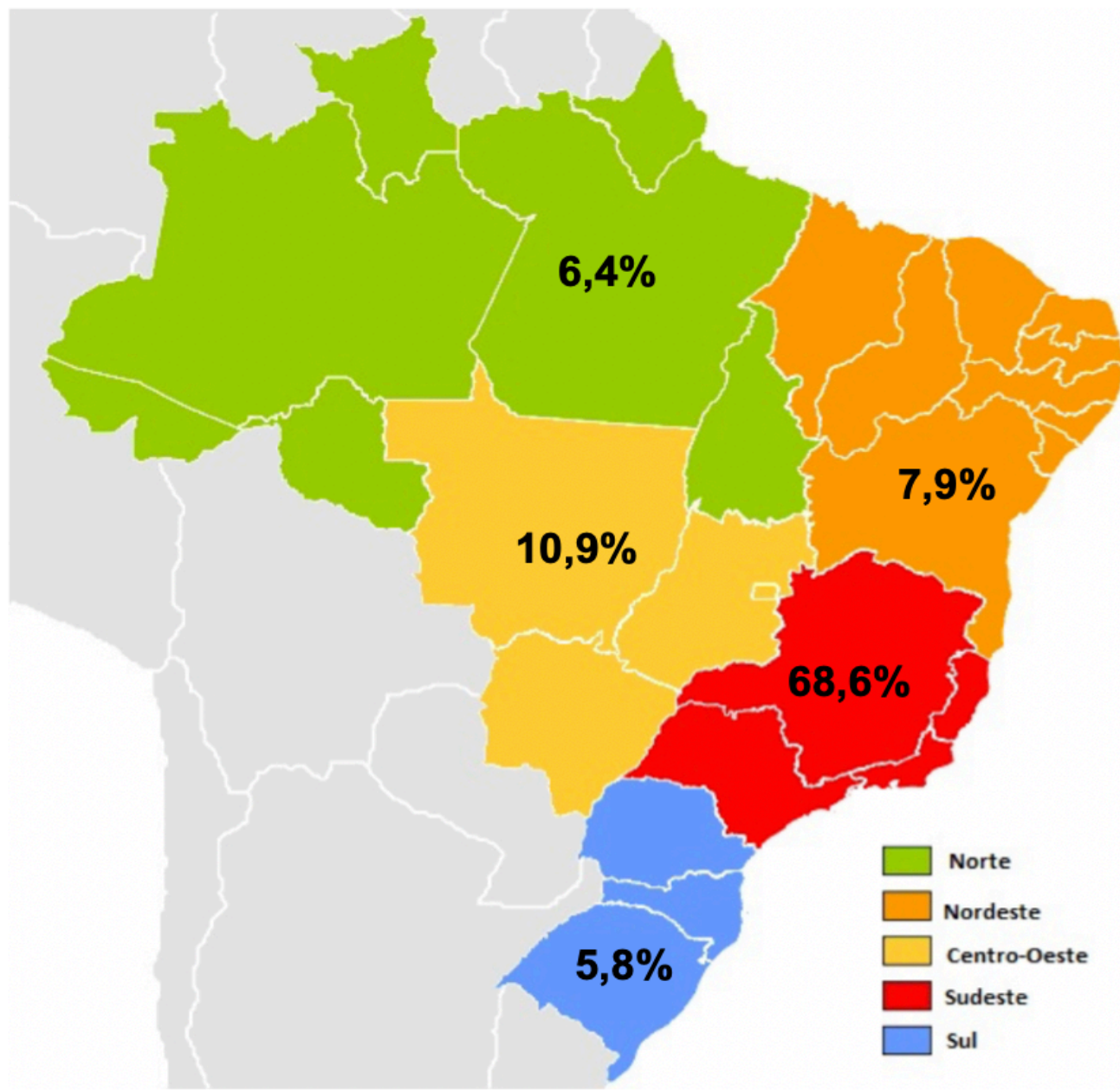

Figura 4 - Mapa brasileiro dividido de acordo com as 5 regiões brasileiras, destacando as porcentagens de sujeitos com diferentes tipos de FL/P não sindrômica analisados no estudo, de acordo com a naturalidade.

\subsection{HISTÓRICO FAMILIAL}

No que se refere ao histórico familial do grupo total de indivíduos analisados, constatamos que este foi positivo para a fissura labiopalatina em 825 casos (31\%) e negativo em 1855 (69\%) (Tabela 4).

Tabela 4 - Quantidade total de sujeitos que relataram histórico familial positivo ou negativo para fissuras labiopalatinas.

\section{Histórico Familial}

\section{Quantidade}

(n)

\section{Porcentagem}

(\%)

\begin{tabular}{ccc}
\hline Positivo & 825 & $31 \%$ \\
Negativo & 1855 & $69 \%$ \\
\hline TOTAL & $\mathbf{2 6 8 0}$ & $\mathbf{1 0 0 \%}$ \\
\hline
\end{tabular}


Em relação à distribuição do sexo entre os indivíduos com $\mathrm{FL} / \mathrm{P}$ não sindrômica com histórico familial positivo nos 8 Subgrupos analisados, constatamos que o sexo masculino foi o mais frequente em 6 dos 8 Subgrupos, com frequência variando de $55 \%$ a $72 \%$ dos casos (Figura 5 ). Os Subgrupos que apresentavam maior frequência de casos de indivíduos do sexo masculino foram: Subgrupo II.b (fissura transforame incisivo bilateral) e Subgrupo I.d (fissura pré-forame incisivo bilateral incompleta). Já nos Subgrupos de fissuras pós-forame incisivo (Subgrupo III.a - fissura pós-forame incisivo completa e Subgrupo III.b - fissura pós-forame incisivo incompleta), o sexo feminino foi o mais acometido, com frequência superior a $70 \%$ em ambos os grupos (Figura 5 ).

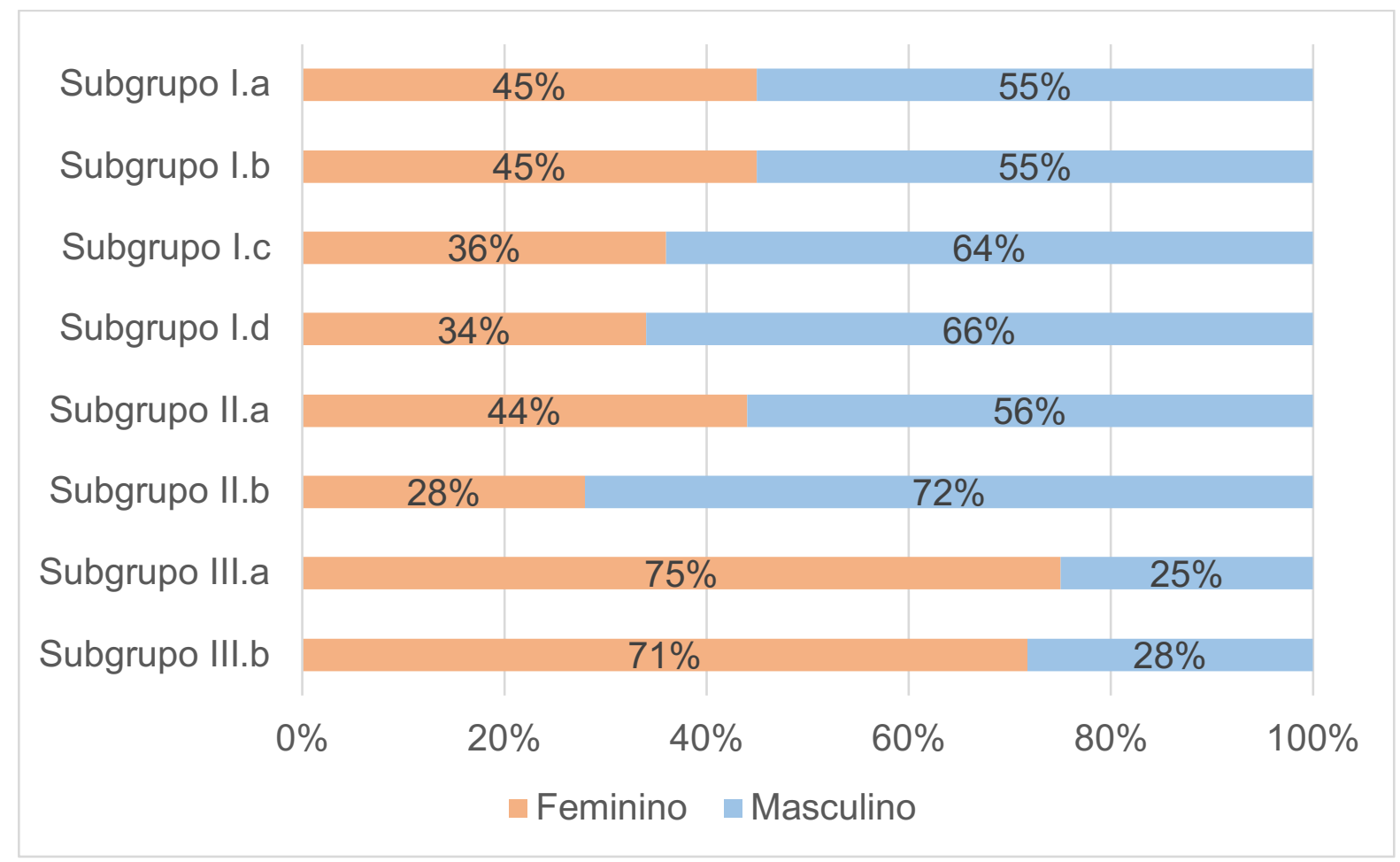

Figura 5 - Distribuição quanto ao sexo dos sujeitos com histórico familial positivo para as fissuras labiopalatinas, distribuídos de acordo com os 8 diferentes Subgrupos.

No que se refere ao local de nascimentos dos indivíduos com histórico familial positivo para as FL/P não sindrômica, contatamos que a maior parte dos sujeitos eram oriundos da região Sudeste do Brasil, totalizando $66,7 \%$ da amostra (Tabela $5)$. 
Tabela 5 - Naturalidade dos indivíduos com histórico familial positivo para a fissura labiopalatina não sindrômica.

\begin{tabular}{ccc}
\hline $\begin{array}{c}\text { Naturalidade dos } \\
\text { Sujeitos }\end{array}$ & $\begin{array}{c}\text { Quantidade } \\
\text { (n) }\end{array}$ & $\begin{array}{c}\text { Porcentagem } \\
\mathbf{( \% )}\end{array}$ \\
\hline Norte & 59 & $7,2 \%$ \\
Nordeste & 78 & $9,5 \%$ \\
Centro-Oeste & 77 & $9,3 \%$ \\
Sudeste & $\mathbf{5 5 0}$ & $\mathbf{6 6 , 7 \%}$ \\
Sul & 57 & $6,9 \%$ \\
Estrangeiro & 2 & $0,2 \%$ \\
Sem informação & 2 & $0,2 \%$ \\
\hline TOTAL & $\mathbf{8 2 5}$ & $\mathbf{1 0 0 \%}$ \\
\hline
\end{tabular}

Em relação aos indivíduos com histórico familial positivo para as $\mathrm{FL} / \mathrm{P}$, ao agruparmos os 8 Subgrupos de fissura nos três grupos principais, com base na classificação das fissuras labiopalatinas proposta por Spina et al. (1992), modificada por Silva Filho et al. (1992), observamos que o maior percentual de histórico familial positivo (36\%) ocorreu no Grupo II (fissura transforame incisivo) (Figura 6, 7 e 8).

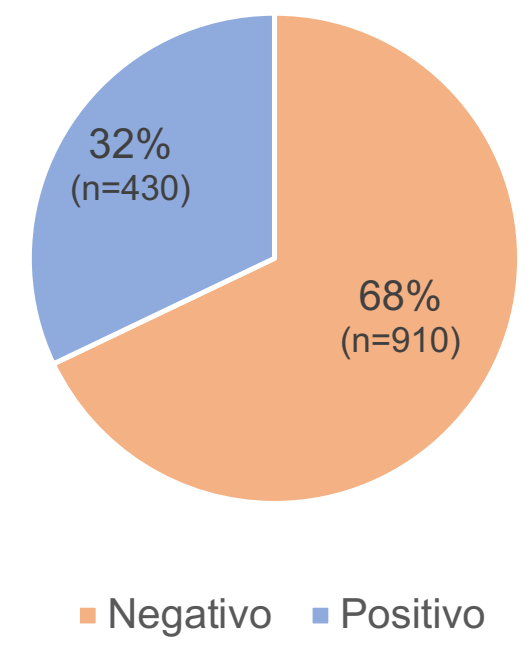

Figura 6 - Quantidade total de sujeitos do Grupo I (fissura pré-forame incisivo) que relataram histórico familial positivo e negativo para as fissuras labiopalatinas. 


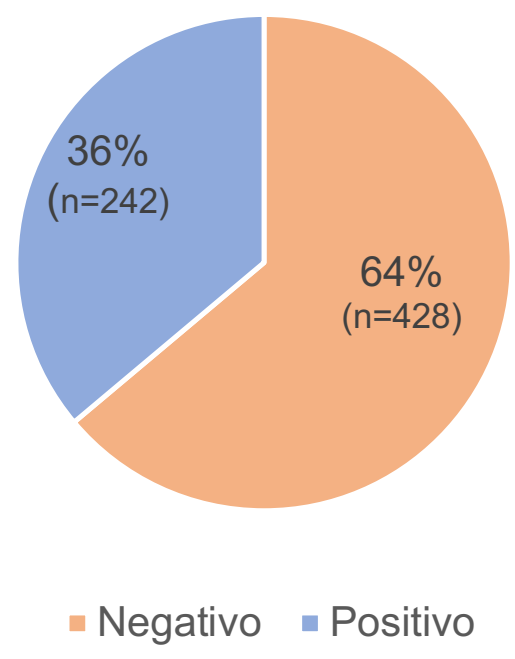

Figura 7 - Quantidade total de sujeitos do Grupo II (fissura transforame incisivo) que relataram histórico familial positivo e negativo para as fissuras labiopalatinas.

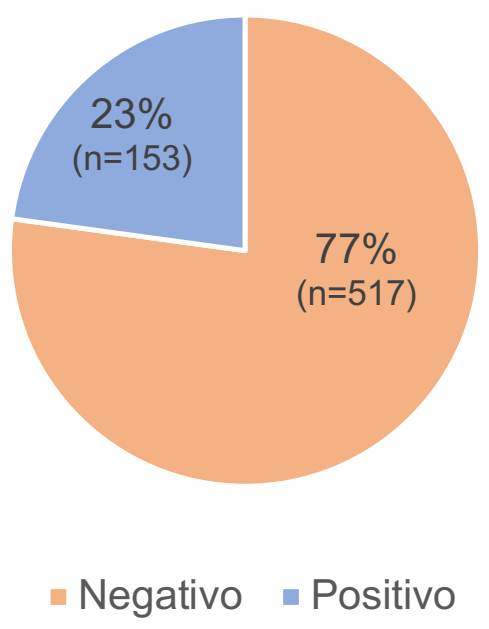

Figura 8 - Quantidade total de sujeitos do Grupo III (fissura pós-forame incisivo) que relataram histórico familial positivo e negativo para as fissuras labiopalatinas.

Ao realizarmos a comparação entre os Grupo I (fissura pré-forame incisivo) com o Grupo II (fissura transforame incisivo), não encontramos diferenças estatisticamente significativas $(p=0,071)$ (Tabela 6).

Tabela 6 - Comparação entre o Grupo I (fissura pré-forame incisivo) com o Grupo II (fissura transforame incisivo), em relação ao histórico familial positivo.

\begin{tabular}{|c|c|c|c|c|c|}
\hline \multirow{2}{*}{$\begin{array}{c}\text { Histórico } \\
\text { Familial }\end{array}$} & \multicolumn{2}{|c|}{ GI $(\mathbf{n = 1 3 4 0})$} & \multicolumn{2}{c|}{ G II $(\mathbf{n = 6 7 0})$} & \multirow{2}{*}{} \\
\cline { 2 - 6 } & $\mathbf{n}$ & $\%$ & $\mathbf{n}$ & $\%$ & $\mathbf{p}$ \\
\hline Positivo & 430 & 32,1 & 242 & 36,1 & 0,071 \\
\hline
\end{tabular}




\begin{tabular}{|l|l|l|l|l|l|}
\hline Negativo & 910 & 67,3 & 428 & 63,9 & \\
\hline
\end{tabular}

Na comparação do Grupo I (fissura pré-forame incisivo) com o Grupo III (fissura pós-forame incisivo) e do Grupo II (fissura transforame incisivo) com o Grupo III (fissura pós-forame incisivo), foram encontradas diferenças estatisticamente significativas $(p<0,001)$ (Tabela 7 e 8$)$.

Tabela 7 - Comparação entre o Grupo I (fissura pré-forame incisivo) com o Grupo III (fissura pós-forame incisivo), em relação ao histórico familial positivo.

\begin{tabular}{|c|c|c|c|c|c|}
\hline \multirow{2}{*}{$\begin{array}{c}\text { Histórico } \\
\text { Familial }\end{array}$} & \multicolumn{2}{|c|}{ GI $(\mathbf{n = 1 3 4 0 )}$} & \multicolumn{2}{|c|}{$\mathbf{G}$ III (n=670) } & \multirow{2}{*}{} \\
\cline { 2 - 5 } & $\mathbf{n}$ & $\mathbf{\%}$ & $\mathbf{n}$ & $\mathbf{\%}$ & $\mathbf{p}$ \\
\hline Positivo & 430 & 32,1 & 153 & 22,8 & \multirow{2}{*}{$\mathbf{0 , 0 0 1}^{*}$} \\
\hline Negativo & 910 & 67,3 & 517 & 77,2 & \\
\hline
\end{tabular}

Tabela 8 - Comparação entre o Grupo II (fissura transforame incisivo) com o Grupo III (fissura pós-forame incisivo), em relação ao histórico familial positivo.

\begin{tabular}{|c|c|c|c|c|c|}
\hline \multirow{2}{*}{$\begin{array}{c}\text { Histórico } \\
\text { Familial }\end{array}$} & \multicolumn{2}{|c|}{ GII $(\mathbf{n = 6 7 0 )}$} & \multicolumn{2}{c|}{ G III $(\mathbf{n = 6 7 0 )}$} & \multirow{2}{*}{} \\
\cline { 2 - 5 } & $\mathbf{n}$ & $\%$ & $\mathbf{n}$ & $\%$ & $\mathbf{p}$ \\
\hline Positivo & 242 & 36,1 & 153 & 22,8 & \multirow{2}{*}{$<\mathbf{0 0 1}^{*}$} \\
\hline Negativo & 428 & 63,9 & 517 & 77,2 & \\
\hline
\end{tabular}

A Figura 9 apresenta os dados sobre o histórico familial, positivo e negativo, de acordo com os 8 diferentes Subgrupos avaliados. Encontramos os maiores valores de histórico familial positivo no Subgrupo II.b (fissura transforame incisivo bilateral), com 125 casos e no Subgrupo I.c (fissura pré-forame incisivo unilateral incompleta), com 121 casos. Os menores valores, de histórico familial positivo, foram encontrados no Subgrupo III.a (fissura pós-forame incisivo completa) e no Subgrupo III.b (fissura pós-forame incisivo incompleta), com valores que variaram de 70 a 83 casos (Figura 9). 


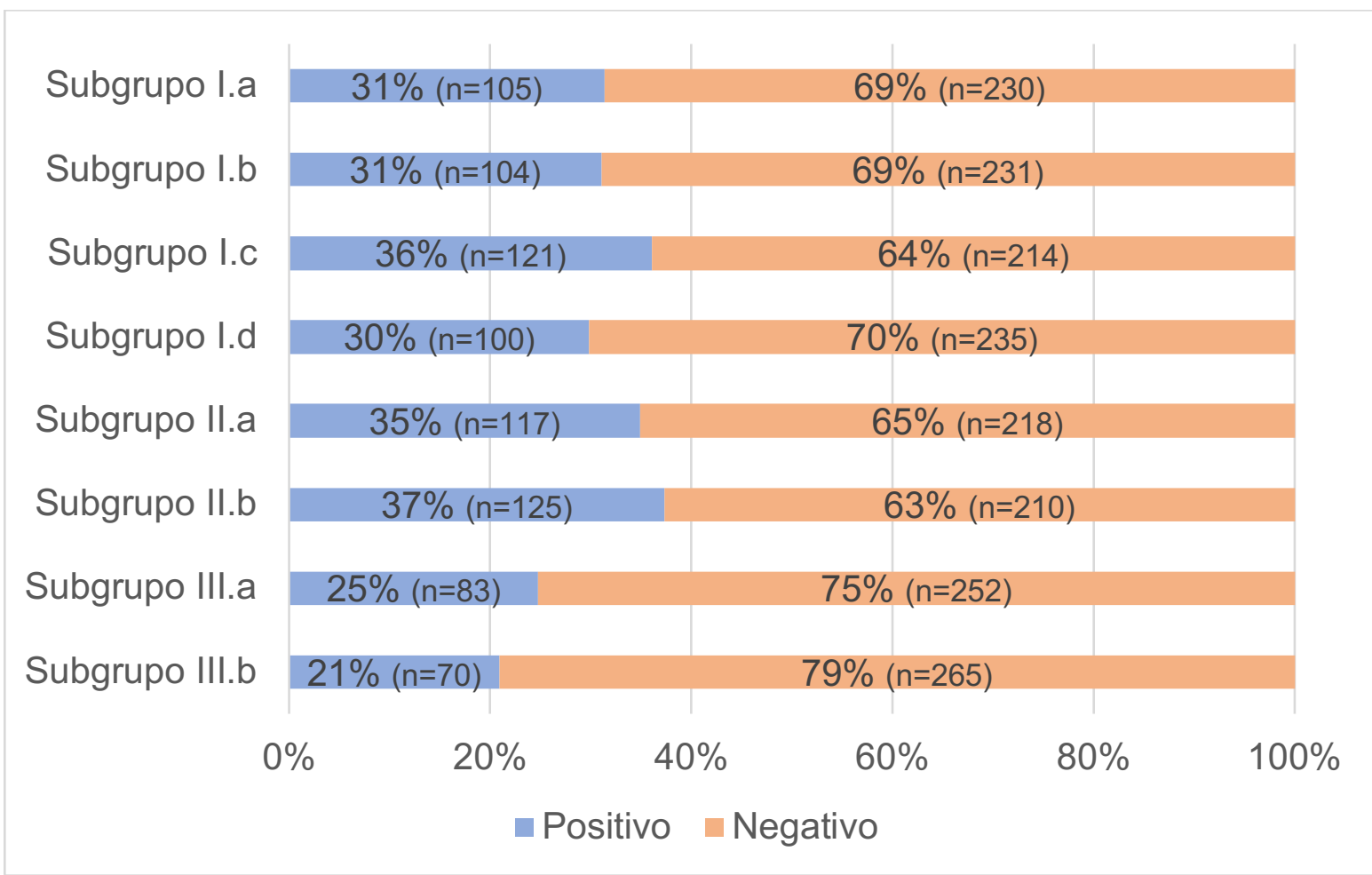

Figura 9 - Distribuição do histórico familial positivo e negativo de acordo com os oito diferentes Subgrupos de sujeitos com FL/P não sindrômica.

Para avaliar possíveis diferenças no que diz respeito ao histórico familial positivo, entre os Subgrupos, eles foram comparados entre si, dentro dos grupos principais.

Estas análises foram realizadas devido ao fato de termos detectado diferenças estatisticamente significativas nas comparações dos grupos principais I e II com o grupo principal III.

Ao efetuarmos a comparação do histórico familial positivo, entre o Subgrupo I.a (fissura pré-forame incisivo unilateral completa) + Subgrupo I.c (fissura préforame incisivo unilateral incompleta) com o Subgrupo I.b (fissura pré-forame incisivo bilateral completa) + Subgrupo I.d (fissura pré-forame incisivo bilateral incompleta) não foram encontradas diferenças estaticamente significativas $(p=0,179)$ (Tabela 9). 
Tabela 9 - Comparação entre os Subgrupos I.a + I.c com os Subgrupos I.b + I.d, em relação ao histórico familial positivo.

\begin{tabular}{|c|c|c|c|c|c|}
\hline \multirow{2}{*}{$\begin{array}{c}\text { Histórico } \\
\text { Familial }\end{array}$} & \multicolumn{2}{|c|}{$\begin{array}{c}\text { Subgrupo I.a + I.c } \\
(\mathbf{n = 6 7 0 )}\end{array}$} & \multicolumn{2}{c|}{$\begin{array}{c}\text { Subgrupo I.b + I.d } \\
(\mathbf{n = 6 7 0 )}\end{array}$} & \multirow{2}{*}{} \\
\cline { 2 - 5 } & $\mathbf{n}$ & $\%$ & $\mathbf{n}$ & $\%$ & $\mathbf{p}$ \\
\hline Positivo & 226 & 34 & 204 & 30 & 0,197 \\
\hline Negativo & 444 & 66 & 446 & 70 & \\
\hline
\end{tabular}

Na comparação entre o Subgrupo I.a (fissura pré-forame incisivo unilateral completa) com o Subgrupo I.c (fissura pré-forame incisivo unilateral incompleta), não constatamos diferença significativa $(p=0,191)$ (Tabela 10). $E$, da mesma forma, não encontramos diferença estatisticamente significativa na comparação entre o Subgrupo I.b (fissura pré-forame incisivo bilateral completa) com o Subgrupo I.d (fissura pré-forame incisivo bilateral incompleta) $(p=0,737)$ (Tabela 11).

Tabela 10 - Comparação entre o Subgrupo I.a com o Subgrupo I.c, em relação ao histórico familial positivo.

\begin{tabular}{|c|c|c|c|c|c|}
\hline \multirow{2}{*}{$\begin{array}{c}\text { Histórico } \\
\text { Familial }\end{array}$} & \multicolumn{2}{|c|}{ Subgrupo I.a $\mathbf{( n = 3 3 5 )}$} & \multicolumn{2}{|c|}{ Subgrupo I.c (n=335) } & \multicolumn{1}{|c|}{$\mathbf{~}$} \\
\cline { 2 - 5 } & $\mathbf{n}$ & $\%$ & $\mathbf{n}$ & $\%$ & \multirow{2}{*}{0,191} \\
\hline Positivo & 105 & 31 & 121 & 36 & \\
\hline Negativo & 230 & 69 & 214 & 64 & \\
\hline
\end{tabular}

Tabela 11 - Comparação entre o Subgrupo I.b com o Subgrupo I.d, em relação ao histórico familial positivo.

\begin{tabular}{|c|c|c|c|c|c|}
\hline \multirow{2}{*}{$\begin{array}{l}\text { Histórico } \\
\text { Familial }\end{array}$} & \multicolumn{2}{|c|}{ Subgrupo I.b $(n=335)$} & \multicolumn{2}{|c|}{ Subgrupo I.d $(n=335)$} & \multirow[b]{2}{*}{$\mathbf{p}$} \\
\hline & $\mathrm{n}$ & $\%$ & $\mathbf{n}$ & $\%$ & \\
\hline Positivo & 104 & 31 & 100 & 30 & \multirow{2}{*}{0,737} \\
\hline Negativo & 231 & 69 & 235 & 70 & \\
\hline
\end{tabular}

Não houve diferença estatisticamente significativa na comparação entre o Subgrupo II.a (fissura transforame incisivo unilateral) e o Subgrupo II.b (fissura transforame incisivo bilateral) $(p=0,519)$ (Tabela 12). 
Tabela 12 - Comparação entre o Subgrupo II.a com o Subgrupo II.b, em relação ao histórico familial positivo.

\begin{tabular}{|c|c|c|c|c|c|}
\hline \multirow{2}{*}{$\begin{array}{l}\text { Histórico } \\
\text { Familial }\end{array}$} & \multicolumn{2}{|c|}{ Subgrupo II.a $(n=335)$} & \multicolumn{2}{|c|}{ Subgrupo II.b $(n=335)$} & \multirow[b]{2}{*}{$\mathbf{p}$} \\
\hline & $n$ & $\%$ & $n$ & $\%$ & \\
\hline Positivo & 117 & 35 & 125 & 37 & \multirow{2}{*}{0,519} \\
\hline Negativo & 218 & 65 & 210 & 63 & \\
\hline
\end{tabular}

E, ao compararmos o Subgrupo III.a (fissura pós-forame incisivo completa) ao Subgrupo III.b (fissura pós-forame incisivo incompleta), também não foram encontradas diferenças estatisticamente significativas $(p=0,231)$ (Tabela 13).

Tabela 13 - Comparação entre o Subgrupo III.a com o Subgrupo III.b, em relação ao histórico familial positivo.

\begin{tabular}{|c|c|c|c|c|c|}
\hline Histórico & \multicolumn{2}{|c|}{ Subgrupo III.a (n=335) } & \multicolumn{2}{|c|}{ Subgrupo III.b (n=335) } & \multicolumn{1}{|c|}{} \\
\cline { 2 - 5 } Familial & $\mathbf{n}$ & $\%$ & $\mathbf{n}$ & $\%$ & $\mathbf{p}$ \\
\hline Positivo & 83 & 25 & 70 & 21 & \multirow{2}{*}{0,231} \\
\hline Negativo & 252 & 75 & 265 & 79 & \\
\hline
\end{tabular}

No que se refere à frequência com que o evento do histórico familial positivo ocorreu, ou seja, na caracterização da quantidade de parentes afetados, ao analisarmos a amostra geral, constatamos que dos 825 indivíduos com histórico familial positivo para as FL/P, o maior percentual de sujeitos (78\%) apresentavam apenas um antecedente de caso na família, ou seja, apresentavam o histórico familial único (Figura 10). 


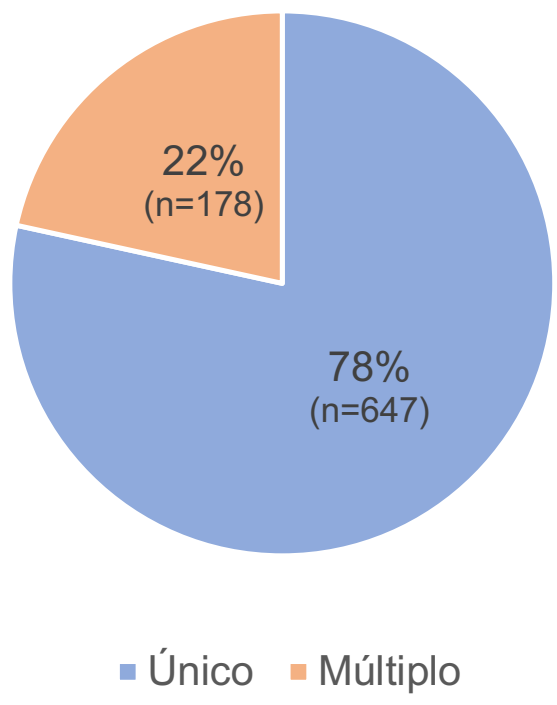

Figura 10 - Número de familiares acometidos pelas fissuras labiopalatinas nos casos de sujeitos com histórico familial positivo, agrupados em único e múltiplo.

Em relação ao agrupamento dos indivíduos, de acordo com a caracterização do histórico familial (único ou múltiplo), considerando os 3 grupos principais, a frequência do histórico familial único foi superior a $75 \%$ nos três grupos. Ao realizarmos a comparação entre o Grupo I (fissura pré-forame incisivo) com o Grupo II (fissura transforame incisivo), não foram encontradas diferenças estatisticamente significativas ( $p=0,301)$. Na comparação entre o Grupo I (fissura pré-forame incisivo) com o Grupo III (fissura pós-forame incisivo), também não foram encontradas diferenças estaticamente significativas $(p=0,602)$. Também não constatamos diferenças significativas na comparação entre o Grupo II (fissura transforame incisivo) com o Grupo III (fissura pós-forame incisivo) $(p=0,206)$ (Tabela 14).

Tabela 14 - Número de familiares acometidos pela FL/P, de acordo com a frequência em que o evento ocorreu, agrupado nos três grupos principais e comparação entre os grupos em relação a quantidade de sujeitos acometidos em cada um deles.

\begin{tabular}{|c|c|c|c|c|c|}
\hline $\begin{array}{c}N^{\circ} \text { de Casos } \\
\text { na Família }\end{array}$ & $\begin{array}{c}G I \\
(n=1340)\end{array}$ & $\begin{array}{c}\text { GII } \\
(n=670)\end{array}$ & $\begin{array}{c}\text { GIII } \\
(n=670)\end{array}$ & GI x GII & GI x GIII \\
\hline
\end{tabular}

Único

(n)

(\%)

340

183

$79,1 \%$

$75,6 \%$

$81 \%$

124

$81 \%$

0,301

0,602

0,206 


\begin{tabular}{cccc}
$(\mathrm{n})$ & 90 & 59 & 29 \\
$(\%)$ & $20,9 \%$ & $24,4 \%$ & $19 \%$ \\
\hline TOTAL & $\mathbf{4 3 0}$ & $\mathbf{2 4 2}$ & $\mathbf{1 5 3}$ \\
\hline
\end{tabular}

Analisando a amostra de indivíduos com histórico familial positivo de forma independente, de acordo com os 8 diferentes Subgrupos de FL/P não sindrômica incluídos neste estudo, no que diz respeito ao número de parentes acometidos pela anomalia, constatamos que o histórico familial único foi o mais frequente em todos os Subgrupos, tendo sua ocorrência variado de $70,9 \%$ dos casos, no Subgrupo II.a (fissura transforame incisivo unilateral), a $87,1 \%$ dos casos, no Subgrupo III.b (fissura pós-forame incisivo incompleta) (Figura 11).

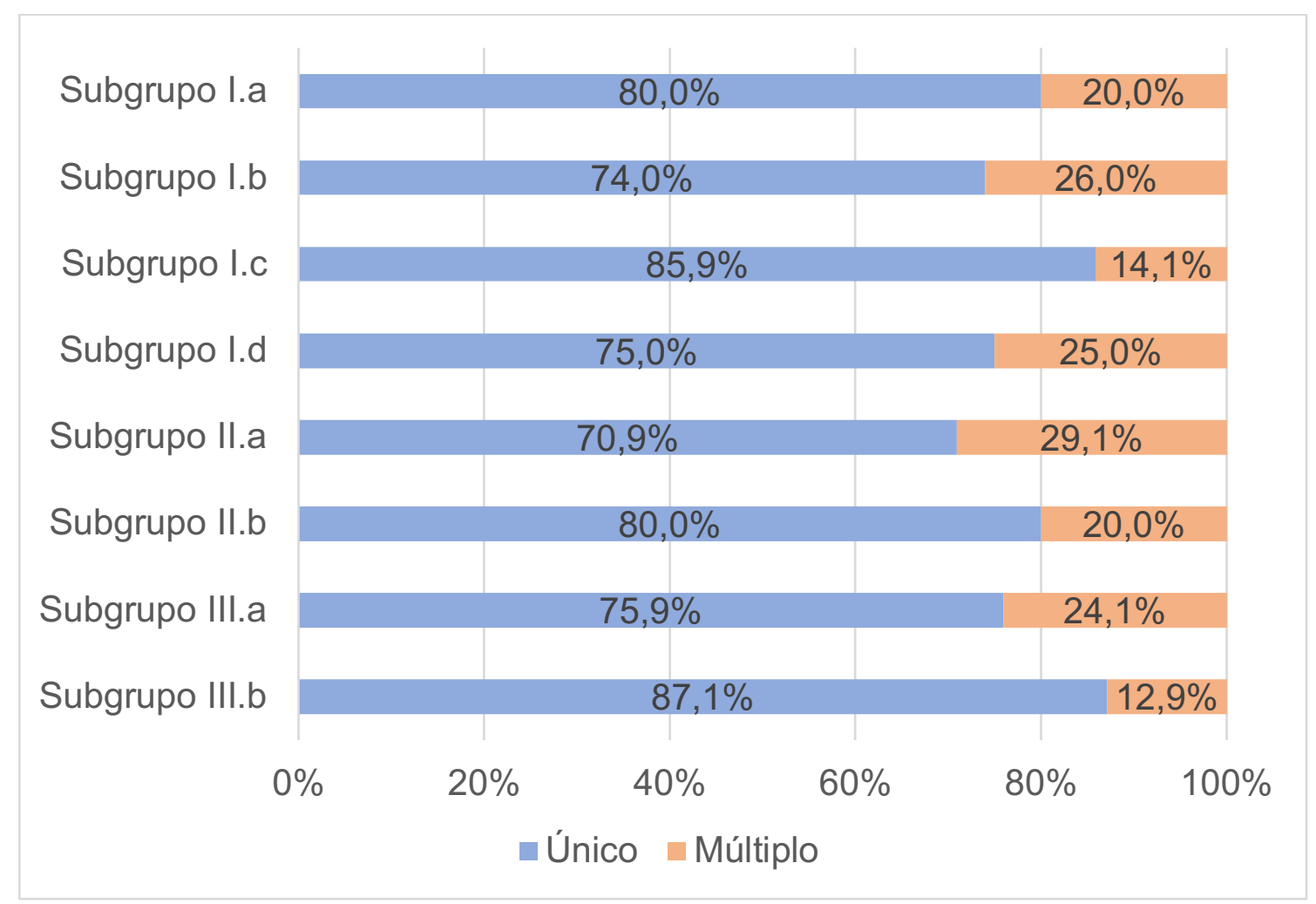

Figura 11 - Quantidade de parentes afetados pela anomalia, distribuídos de acordo com os 8 diferentes Subgrupos de fissuras labiopalatinas não sindrômica analisados.

Quanto ao total de parentes afetados, quando analisamos o total de sujeitos com histórico positivo $(n=825)$, sem o agrupamento em Subgrupos específicos, encontramos um total de 1072 parentes afetados. 
A Tabela 15 abaixo apresenta para o grupo total, o grau de parentesco do indivíduo da família acometido pela fissura, em relação ao sujeito analisado, sendo que o grau de parentesco, conforme descrito na metodologia, foi dividido amplamente em 9 categorias. O grau de parentesco mais frequente foi: parentesco distante, com 456 casos; seguido por pai ou mãe, com 107 casos. Ressalta-se aqui que, em um grande número de parentes afetados $(n=212)$, não constava no registro médico informação precisa sobre o grau de parentesco do parente afetado pela fissura.

Tabela 15 - Grau de parentesco dos parentes acometidos pelas fissuras labiopalatinas, nos casos de histórico familial positivo.

\begin{tabular}{ccc}
\hline Grau de Parentesco & Quantidade & Porcentagem \\
& $(\mathbf{n})$ & $\mathbf{( \% )}$ \\
\hline Pai/Mãe & 107 & $10 \%$ \\
Irmão (ã) & 91 & $8,5 \%$ \\
Avô (ó) & 31 & $2,9 \%$ \\
Tio (a) & 75 & $7 \%$ \\
Sobrinho (a) & 17 & $1,6 \%$ \\
Meio-irmão (ã) & 9 & $0,8 \%$ \\
Primo (a) de 10 grau & 74 & $6,9 \%$ \\
Distante & 456 & $42,5 \%$ \\
Sem Informação precisa & 212 & $18,8 \%$ \\
\hline TOTAL & 1072 & $\mathbf{1 0 0 \%}$ \\
\hline
\end{tabular}

Analisando o grau de parentesco somente dos casos em que havia informação precisa $(n=404)$, de acordo com a classificação proposta por Nussbaum, McInnes e Willard (2016), constatamos que o parentesco de $1^{\circ}$ grau foi o mais frequente (Tabela 16).

Tabela 16 - Grau de parentesco dos parentes acometidos pelas fissuras, distribuídos segundo a classificação e Nussbaum, McInnes e Willard (2016).

Grau de Parentesco

\section{Quantidade}

(n)

132

$\begin{array}{ccc}1^{\circ} \text { grau } & 198 & 49 \% \\ 2^{\circ} \text { grau } & 132 & 32,7 \%\end{array}$

Porcentagem

(\%) 


\begin{tabular}{ccc}
$3^{\circ} \mathrm{grau}$ & 74 & $18,3 \%$ \\
\hline TOTAL & $\mathbf{4 0 4}$ & $\mathbf{1 0 0 \%}$ \\
\hline
\end{tabular}

A Figura 12 apresenta os dados minerados acerca do grau de parentesco do parente afetado pela fissura considerando a distribuição dos probandos nos 3 grupos principais de fissuras (Grupo I, Grupo II e Grupo III). Analisando somente o grau de parentesco, definido de acordo com a classificação proposta por Nussbaum, McInnes e Willard (2016), é possível constatar que nos 3 grupos os maiores percentuais de parentes afetados eram parentes de $1^{\circ}$ grau.

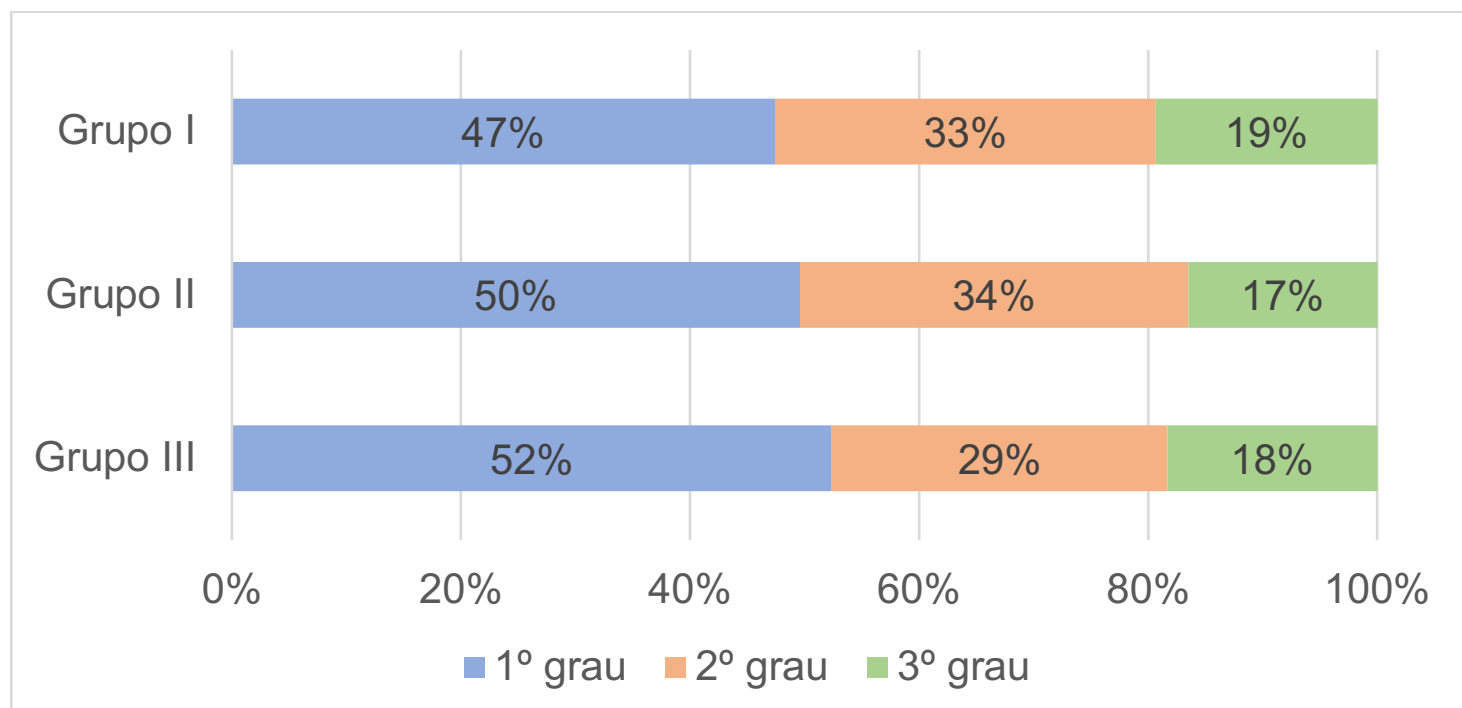

Figura 12 - Grau de parentesco do parente acometido pela FL/P distribuídos nos 3 grupos principais de probandos analisados.

Analisando de forma independente os 8 diferentes Subgrupos de sujeitos avaliados neste estudo, constatamos que conforme observado nos 3 grupos principais, foi mantido o predomínio de parentes em primeiro grau acometidos pela fissura, com pequenas variações percentuais no comparativo entre os Subgrupos (Tabela 17).

Tabela 17 - Grau de parentesco dos parentes dos sujeitos acometidos pelas fissuras, distribuídos de acordo com os 8 diferentes Subgrupos de fissuras labiopalatinas, segundo a classificação de Nussbaum, McInnes e Willard (2016).

Grau de Parentesco

Quantidade

(n)
Porcentagem

(\%)

\footnotetext{
Subgrupo I.a
} 


$$
\begin{gathered}
1^{\circ} \text { grau } \\
2^{\circ} \text { grau } \\
3^{\circ} \text { grau } \\
\text { Total }
\end{gathered}
$$

Subgrupo I.b

$$
\begin{gathered}
1^{\circ} \text { grau } \\
2^{\circ} \text { grau } \\
3^{\circ} \text { grau } \\
\text { Total }
\end{gathered}
$$

Subgrupo I.C

$$
\begin{gathered}
1^{\circ} \text { grau } \\
2^{\circ} \text { grau } \\
3^{\circ} \text { grau } \\
\text { Total }
\end{gathered}
$$

Subgrupo I.d

$$
\begin{gathered}
1^{\circ} \text { grau } \\
2^{\circ} \text { grau } \\
3^{\circ} \text { grau } \\
\text { Total }
\end{gathered}
$$

Subgrupo II.a

$$
\begin{gathered}
1^{\circ} \text { grau } \\
2^{\circ} \text { grau } \\
3^{\circ} \text { grau } \\
\text { Total }
\end{gathered}
$$

Subgrupo II.b

$$
\begin{gathered}
1^{\circ} \text { grau } \\
2^{\circ} \text { grau } \\
3^{\circ} \text { grau } \\
\text { Total }
\end{gathered}
$$

Subgrupo III.a

$$
\begin{gathered}
1^{\circ} \text { grau } \\
2^{\circ} \text { grau } \\
3^{\circ} \text { grau } \\
\text { Total }
\end{gathered}
$$

$45,7 \%$

14 $30,4 \%$ $23,9 \%$ $100 \%$
$51,7 \%$

$37,9 \%$

$10,3 \%$

$100 \%$

$\begin{array}{cc}24 & 45,3 \% \\ 20 & 37,3 \% \\ 9 & 17 \% \\ & 100 \%\end{array}$

Subgrupo III.b 


\begin{tabular}{ccc}
$2^{\circ}$ grau & 10 & $25,6 \%$ \\
$3^{\circ}$ grau & 7 & $17,9 \%$ \\
Total & & $100 \%$ \\
\hline TOTAL & 404 & \\
\hline
\end{tabular}

Em relação ao tipo de fissura encontrada nos parentes afetados, estas foram classificadas de acordo com Spina et al. (1972), modificada por Silva Filho et al. (1992), em: Grupo I - fissura pré-forame incisivo; Grupo II - fissura transforme incisivo; e, Grupo III - fissura pós-forame incisivo).

Para essa análise, foram excluídos 748 parentes afetados, devido a escassez de informações. Além disso, foram excluídos desta análise, os parentescos distantes e sem informação precisa.

Desta forma, foram utilizados para essa análise do tipo de fissura do parente acometido, 324 parentes, os quais apresentavam parentesco em $1^{\circ}, 2^{\circ}$ ou $3^{\circ}$ grau, de acordo com Nussbaum, Mclnnes e Willard (2016) e, também, necessariamente apresentavam informações nos prontuários médicos arquivados referentes ao tipo de fissura do parente acometido.

Na Tabela 18 são apresentados os dados do grupo total sobre os tipos de fissuras encontrados nos familiares acometidos pela malformação. É possível observar que, de forma geral, o tipo de fissura mais frequentemente encontrado, nos parentes de sujeitos com fissuras não sindrômicas, foi a fissura transforme incisivo, a qual esteve presente em 142 dos 324 parentes relatados.

Tabela 18 - Tipo de fissura encontrada no familiar acometido pela anomalia, classificado de acordo com a classificação de Spina et al. (1972), modificada por Silva Filho et al. (1992).

Tipo de Fissura

\section{Quantidade}

(n)

\begin{tabular}{ccc}
\hline Fissura pré-forame incisivo & 112 & $34,6 \%$ \\
Fissura transforame incisivo & 142 & $43,8 \%$ \\
Fissura pós-forame incisivo & 70 & $21,6 \%$ \\
\hline TOTAL & 324 & $100 \%$ \\
\hline
\end{tabular}

\section{Porcentagem}

(\%)

$34,6 \%$

$100 \%$ 
A Figura 13 mostra o tipo de fissura do parente afetado, quando os probandos foram distribuídos nos 3 grupos principais de fissuras labiopalatinas. Nota-se que nos probando do Grupo I (fissura pré-forame incisivo) foram encontrados mais casos de parentes acometidos pela fissura transforame incisivo, com $51 \%$ dos casos, seguido da fissura pré-forame incisivo, com $45 \%$ dos casos. Os probandos do Grupo II (fissura transforame incisivo) também apresentaram mais casos de parentes acometidos pela fissura transforame incisivo, estando, esta, presente em $59 \%$ dos casos; seguido pela fissura pré-forame incisivo, presente em $36 \%$ dos casos. Já nos probandos do Grupo III (fissura pós-forame incisivo), 83\% dos parentes apresentavam fissura pós-forame incisivo.

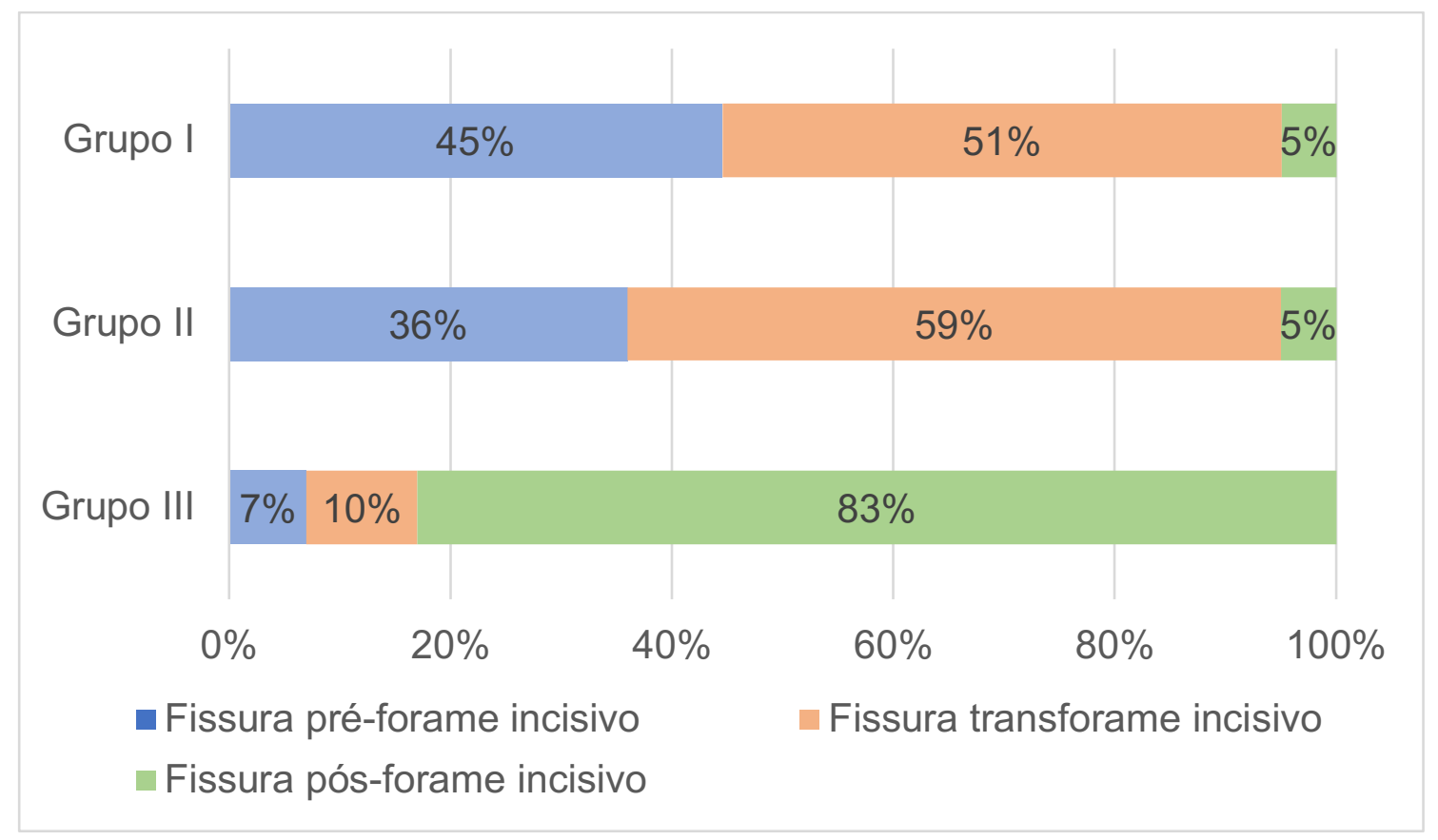

Figura 13 - Distribuição do tipo de fissura encontrada nos parentes dos indivíduos estudados distribuídos de acordo com os 3 grupos principais.

$\mathrm{Na}$ Tabela 19 são apresentados os resultados dos tipos de fissuras dos parentes acometidos pela anomalia considerando cada um dos 8 Subgrupos de probandos analisados. Constatamos que nos Subgrupos I.a, I.b, I.c, II.a e II.b o tipo de fissura mais frequentemente encontrada no parente afetado, foi a fissura transforame incisivo, tendo sua frequência variado de $54,4 \%$ a $64,3 \%$ dos casos. No Subgrupo I.d, o tipo de fissura mais encontrado nos familiares, foi a fissura préforame incisivo, representando, esta, $61,1 \%$ dos casos. Nos Subgrupos III.a e III.b, o 
tipo de fissura mais encontrado foi a pós-forame incisivo, com a frequência variando de $81,8 \%$ a $83,8 \%$ dos parentes afetados.

Tabela 19 - Tipo de fissura encontrada nos parentes dos indivíduos com FL/PNS, distribuídos de acordo com os 8 Subgrupos, sendo o tipo de fissura do parente afetado classificado de acordo com Spina et al. (1972), modificada por Silva Filho et al. (1992).

\begin{tabular}{l} 
Subgrupos e Tipos de \\
Fissura do Parente \\
afetado \\
\hline $\begin{array}{l}\text { Subgrupo I.a - Fissura } \\
\text { pré-forame incisivo } \\
\text { unilateral completa }\end{array}$
\end{tabular}

Quantidade

(n)
14

27
(\%)

\section{Porcentagem}

\section{Fissura pré-forame incisivo \\ Fissura transforame incisivo \\ Fissura pós-forame incisivo \\ Total \\ Subgrupo I.b - Fissura pré-forame incisivo bilateral completa}

Fissura pré-forame incisivo

Fissura transforame incisivo

Fissura pós-forame incisivo

\section{Subgrupo I.c - Fissura pré-forame incisivo unilateral incompleta}

Fissura pré-forame incisivo 6 $28,6 \%$

Fissura transforame incisivo

Fissura pós-forame incisivo

\section{Subgrupo I.d - Fissura pré-forame incisivo bilateral incompleta}

Fissura pré-forame incisivo

Fissura transforame incisivo

Fissura pós-forame incisivo 
transforame incisivo

Fissura pré-forame incisivo 12

$35,3 \%$

Fissura transforame incisivo

$55,9 \%$

Fissura pós-forame incisivo

$8,8 \%$

Total

\section{Subgrupo II.b - Fissura transforame incisivo bilateral}

Fissura pré-forame incisivo

Fissura transforame incisivo

Fissura pós-forame incisivo

\section{Subgrupo III.a - Fissura pós-forame incisivo completa}

Fissura pré-forame incisivo

Fissura transforame incisivo

Fissura pós-forame incisivo

\section{Subgrupo III.b - Fissura pós-forame incisivo incompleta}

Fissura pré-forame incisivo

Fissura transforame incisivo

Fissura pós-forame incisivo 
5 DISCUSSÃO 



\section{DISCUSSÃO}

O desenvolvimento da cabeça e da face é um dos eventos mais complexos que ocorre durante o desenvolvimento embrionário (AHMED; BUI; TAIOLI, 2017). Falhas durante esse desenvolvimento, podem levar a ocorrência das fissuras labiopalatinas - anomalias craniofaciais congênitas (FREITAS et al., 2012). Esta malformação apresenta diferentes padrões fenotípicos de manifestação clínica e é considerada uma anomalia com herança complexa. Doenças complexas, geralmente, resultam da interação de alelos de mais de um lócus gênico associado a fatores ambientais (NUSSBAUM; MCINNES; WILLARD, 2016). Apesar das fissuras labiopalatinas representarem a anomalia craniofacial mais comum, por se tratar de uma alteração complexa e por apresentar diversos padrões fenotípicos de manifestação clínica, a etiologia ainda não foi completamente esclarecida.

Dentre os aspectos etiológicos relacionados com as FL/PNS, verificamos que a literatura atual tem focado, basicamente, em dois fatores primordiais: os maternos, os quais incluem exposição a agentes ambientais no primeiro trimestre da gestação; e os fatores genéticos, os quais incluem histórico familial, genes específicos e consanguinidade parental (AQUINO, et al., 2011; MITCHELL et al., 2002; SILVA et al., 2019).

A longo tempo, os aspectos relacionados ao histórico familial e a recorrência familial vêm sendo estudados. Tais investigações se mostram pertinentes, uma vez que são constatados mais casos de fissuras labiopalatinas em familiares de sujeitos com fissura, comparativamente a ocorrência de casos isolados. Nesse sentido, alguns autores acreditam que casos esporádicos de fissura, sem histórico familial positivo, podem estar mais relacionados aos riscos ambientais, enquanto a presença de um ou mais afetados, na mesma família, sugere fortemente que os fatores genéticos são os principais fatores envolvidos (SETÓ-SALVIA; STANIER 2014).

Devido ao fato de que os genes podem ser compartilhados entre familiares, o histórico familial pode fornecer informações sobre um possível impacto que a herança genética de um indivíduo poderia ter sobre a saúde. É viável, em algumas 
condições, utilizar o histórico clínico de parentes como um indicador das susceptibilidades genéticas da própria pessoa (NUSSBAUM; MCINNES; WILLARD, 2016).

Por estas razões, neste estudo retrospectivos, buscamos detalhar as questões relativas ao histórico familial entre os diferentes tipos de fissuras labiopalatinas, pois definir o perfil de histórico familial nos permite entender alguns dos aspectos relacionados à etiologia das FL/PNS e inferir sobre possíveis fatores de risco em potencial para essa anomalia, contribuindo, significativamente, na definição de grupos de risco predispostos a malformação, população essa que deve ser alvo de atenção em políticas públicas de prevenção dos defeitos ao nascimento com impacto socioeconômico significativo para o país, pois a partir desses dados é possível estabelecer protocolos de aconselhamento genético fundamentados em gerenciamento de risco.

No presente estudo nós encontramos $31 \%$ de histórico familial positivo nos 2680 casos avaliados, ou seja, 825 probandos apresentavam pelo menos um parente com esta mesma malformação. Ao revisar a frequência do histórico familial positivo descrita na literatura em diferentes estudos, avaliando sujeitos em diversas regiões do país, verifica-se que no Brasil esta variou de $22 \%$ a 45,7\% (SOUZAFREITAS, 2004; LEITE; KOIFMAN, 2009; BRITO et al., 2011; ALVAREZ; GUIONALMEIDA; RICHIERI-COSTA, 2014; FALAGAN-LOTSCH et al., 2015). Os autores Alvarez, Guion-Almeida e Richieri-Costa (2014) acreditam que essas discrepâncias de proporções encontradas em diferentes estudos sejam atribuídas a população estudada em cada estudo e, também, atribuem a diferenças metodológicas adotadas. Para Brito e colaboradores (2011), as diferenças encontradas parecem estar relacionadas com a região em que a amostra foi coletada, pois os autores encontraram em Maceió, uma frequência de 23\% de histórico familial positivo e em Santarém uma frequência de $44 \%$. Além disso, os autores verificaram, após uma análise de herdabilidade, que houve uma menor contribuição genética em Maceió e, nesta região, os autores acreditam que os fatores ambientais possam ter um maior impacto na etiologia das fissuras labiopalatinas não sindrômicas, quando comparada com as demais. 
Ao analisarmos o percentual de histórico familial positivo mundial, nos deparamos com estudos realizados na Malásia, onde a frequência do histórico familial positivo variou de $19 \%$ a $59,5 \%$, porém estes dados precisam ser interpretados com cautela, uma vez que nenhum dos artigos discute a respeito das diferenças encontradas e, ainda, nenhum deles têm como foco principal fazer uma análise aprofundada do perfil do histórico familial positivo encontrado naquela região (SALAHSHOURIFAR et al., 2012; YEW; ALAM; RAHMAN, 2016; HAQUE; ALAM; KHAMIS, 2017; ARSHAD; ALAM; KHAMIS, 2018).

Analisando a população Chinesa no que se refere as taxas de histórico familial positivo, verificamos que a frequência desta vertente do aspecto genético variou de 9,86\% a 17,2\% (ZENG et al., 2015; LI et al., 2016; NEOGI et al., 2017). Constatamos que dois destes três estudos eram de caso-controle e os autores consideravam que o histórico familial positivo tinha associação com o risco aumentado para as fissuras labiopalatinas não sindrômicas. Porém, o que nos intriga é que a população desta etnia, a amarela, apresenta as maiores taxas epidemiológicas para esse defeito congênito, ou seja, nesta região ocorrem mais nascimentos de crianças com fissura labiopalatina, quando comparada as demais regiões do mundo. Mas quando analisamos o histórico familial, eles apresentam taxas muito inferiores àquelas encontradas em populações de outras etnias, como a caucasiana. Em nenhum destes três estudos os autores comparam as frequências de histórico familial positivo encontrada com a literatura mundial. Acreditamos que estes baixos valores de histórico familial positivo possam indicar que, nesta região, a FL/PNS possa estar mais fortemente relacionada aos fatores ambientais.

Em outros países como, Irã, Reino Unido, República Democrática do Congo, Alemanha, Estados Unidos e Colômbia, os valores do histórico familial positivo variaram de $8 \%$ a 38,77\% (HOLDER et al., 1992; BEATY et al., 2001; ZAPATA et al., 2010; ABDOLLAHI-FAKHIM et al., 2015; REITER et al., 2015; MBUYI-MUSANZAYI et al., 2018). Nenhum dos autores discute sobre as frequências do histórico familial positivo encontradas. Devido a essa escassez de informações na literatura, no que diz respeito a comparação entre diferentes frequências de histórico familial positivo, não conseguimos concluir o porquê essas diferenças ocorreram. A partir desses dados é possível inferir que nas populações com altas taxas de histórico familial 
positivo, o componente genético poderia estar fortemente associado a esta anomalia e, nas populações onde as taxas de histórico familial positivo foram baixas, o fator ambiental poderia ser o agente etiológico determinante para a ocorrência da fissura labiopalatina não sindrômica.

Nesta primeira análise geral dos percentuais de histórico familial encontradas, observa-se que a frequência geral de $31 \%$ de histórico familial positivo encontrada no presente estudo se enquadra nas variações percentuais encontradas em estudos realizados em diferentes etnias não considerando o tipo especifico de fissura do probando avaliado, uma vez que os estudos descreveram esta característica agrupando todos os sujeitos com diferentes tipos de FL/PNS em um único grupo e foi apresentado o percentual positivo desta característica familial. Porém o detalhamento das frequências específicas de histórico positivo levando em consideração o tipo de fissura do probando avaliado é de grande valia, pois busca definir padrões de risco a partir da fissura apresentada pelo sujeito.

Para verificar os percentuais de histórico familial positivo nos diferentes tipos de fissuras estudados, inicialmente realizamos a análise desta vertente de acordo com o tipo de fissura encontrada no sujeito avaliado, seguindo a classificação proposta por Spina et al. (1972), modificada por Silva Filho et al. (1992), considerando assim os três grupos principais de fissura. No Grupo I (fissura préforame incisivo) a taxa de histórico familial positivo encontrada foi de $32 \%$; no Grupo II (fissura transforame incisivo) $36 \%$; e, as menores taxas foram encontradas no Grupo III (fissura pós-forame incisivo), com $23 \%$ dos casos. Analisando os tipos de fissuras labiopalatinas, agrupadas desta forma, podemos dizer que as maiores taxas percentuais de histórico familial positivo foram encontradas nas fissuras mais complexas, as transforame incisivo. Esta informação percentual confirma a hipótese inicial deste estudo, na qual acreditava-se que as formas mais complexas de fissura labiopalatina, no caso as fissuras transforame incisivo (unilateral e bilateral), seriam as que apresentariam as maiores frequências de histórico familial positivo para esta anomalia, quando comparada aos demais tipos de fissura (fissura pré-forame incisivo e fissura pós-forame incisivo). A partir desse dado, é possível inferir que nas famílias de sujeitos com essas formas mais complexas de fissuras labiopalatinas, as 
transforame incisivo, a chance de encontrarmos um outro parente, também afetado por esta anomalia, é maior, quando comparada aos demais grupos estudados.

$\mathrm{Na}$ literatura existem poucos estudos que separam as taxas de histórico familial positivo, de acordo com o tipo de fissura do sujeito avaliado. Embora seja reduzido o número de trabalhos que analisaram o percentual do histórico familial em diferentes grupos de fissuras labiopalatinas, encontramos um estudo semelhante ao nosso, porém realizado com uma amostra menor, de 218 sujeitos, o qual foi realizado por Falagan-Lotsch e colaboradores (2015), no Rio de Janeiro. Nesta investigação, os autores analisaram o percentual de histórico familial positivo para as fissuras labiopalatinas, de acordo também com os 3 grandes grupos de fissuras e encontraram os seguintes resultados: dos 39 sujeitos com fissura pré-forame incisivo, $8(20,5 \%)$ tiveram histórico familial positivo; dos 152 com fissura transforame incisivo, $38(25 \%)$ apresentavam, pelo menos, um outro parente também acometido por esta anomalia; e, dos 27 com fissura pós-forame incisivo, 4 $(14,8 \%)$ tiveram histórico familial positivo. Esses dados diferem dos percentuais de histórico familial positivo encontrados no presente estudo, mas confirmam, assim como em nosso estudo, que os sujeitos com fissura transforame incisivo são os que apresentam as maiores taxas de histórico familial positivo para as fissuras labiopalatinas, seguido pelos sujeitos com fissura pré-forame incisivo e, por fim, os sujeitos com fissura pós-forame incisivo.

Analisando isoladamente o percentual de histórico familial positivo do Grupo III (fissura pós-forame incisivo), encontramos uma investigação conduzida por Garbieri (2016), a qual constatou que dos 144 sujeitos analisados com este tipo de fissura, 41 deles $(28,47 \%)$ tinham mais pelo menos um outro parente afetado por essa anomalia. Este dado é superior ao encontrado nesta dissertação, a qual constatou que $23 \%$ de sujeitos, com este tipo de fissura apresentavam histórico familial positivo, porém esta diferença pode ter ocorrido devido ao tamanho da amostra, pois na avaliação deste tipo de fissura no presente estudo utilizamos 526 sujeitos a mais do que o analisado no estudo citado. Além do que, no estudo de Garbieri, na estratificação de acordo com as estruturas anatômicas do palato acometidas, somente 19 sujeitos apresentavam fissura de palato completa, o que pode ser considerada uma amostra bastante reduzida para esse tipo de 
detalhamento do histórico familial, estando sujeita a variações individuais. Para evitar esse tipo de variabilidade da amostra, acreditamos que quanto maior o número amostral, maiores serão as chances de a informação estar próxima ao real encontrado na população.

Um outro problema encontrado na literatura, no tocante ao histórico familial, em diferentes tipos de fissuras labiopalatinas, está relacionado com a forma como alguns autores fazem o agrupamento dos diferentes tipos de fissuras encontrados. É visto, com grande frequência, a composição de um grupo único incluindo as fissuras pré-forame incisivo e as fissuras transforame incisivo. Porém acreditamos que este agrupamento não seja o ideal, uma vez embriologicamente há envolvimento e acometimento de diferentes estruturas anatômicas. Um exemplo de um estudo que fez este agrupamento, foi o conduzido por Zeng e colaboradores (2015) na China. Os autores dividiram as FL/PNS em dois grupos, no Grupo I, incluíram as fissuras pré-forame incisivo e as fissuras transforame incisivo, ou seja, as fissuras que acometiam o lábio com ou sem o acometimento do palato e, no Grupo II, incluíram apenas as fissuras pós-forame incisivo, as fissuras de palato isoladas. Utilizando essa estratificação dos grupos, os autores verificaram quais eram os percentuais de histórico familial positivo encontrados em ambos os grupos e, foi constatado que, no Grupo I, dos 206 sujeitos analisados, 25 (12,13\%) apresentavam, pelo menos, um outro parente acometido por esta anomalia e, no Grupo II, dos 88 sujeitos avaliados, apenas $4(4,5 \%)$ apresentavam mais casos de fissura labiopalatina na família. Embora esses autores tenham encontrado frequências de histórico familial positivo baixas, podemos verificar que as frequências encontradas no Grupo I, fissura préforame incisivo e fissura transforame incisivo, foram percentualmente superiores, quando comparadas com o Grupo II, sujeitos que apresentavam apenas a fissura pós-forame incisivo. Apesar dessa importante diferença percentual entre as taxas de histórico familial positivo encontradas no presente estudo quando comparadas às encontradas por Zeng e colaboradores (2015), os dados deles corroboram com os encontrados neste estudo, uma vez que foi constatado que a frequência de histórico familial positivo é inferior em famílias de sujeitos que apresentam apenas a fissura pós-forame incisivo. 
Ao compararmos os três diferentes grupos de tipos de fissura labiopalatina, no que diz respeito ao percentual de casos com o histórico familial positivo para essa anomalia, verificamos diferenças estatisticamente significativas quando as comparações envolviam a fissura pós-forame incisivo, ou seja, quando esta foi comparada à fissura pré-forame incisivo e à transforame incisivo. Estes resultados se mostram condizentes, uma vez que se verifica na literatura, conforme descrito anteriormente, que a fissura pós-forame incisivo é a que apresenta as menores taxas de casos de sujeitos com histórico familial positivo. Não encontramos nenhum estudo que buscasse comparar as taxas de histórico familial positivo entre diferentes tipos de fissura. Isso demonstra que o presente estudo além de apresentar o maior número amostral encontrado em estudos com este objetivo, também apresenta, como diferencial, ser um estudo pioneiro nestas análises, buscando identificar, de forma detalhada, os grupos de sujeitos com os maiores percentuais de histórico familial positivo para as fissuras labiopalatinas não sindrômicas, grupos, estes, que merecem mais atenção em programas de aconselhamento genético.

Ainda, para compreender de forma detalhada os percentuais de histórico familial positivo nos 8 diferentes Subgrupos analisados, de acordo com a complexidade de estruturas acometidas e lateralidade com que o defeito ocorreu, observa-se que a maior taxa de histórico familial positivo (37\%) foi encontrada no Subgrupo II.b (fissura transforame incisivo bilateral), seguido de $36 \%$ encontrada no Subgrupo I.c (fissura pré-forame incisivo unilateral incompleta) e 35\% no Subgrupo II.a (fissura transforame incisivo unilateral). As menores taxas de histórico familial positivo foram encontradas no Subgrupo III.a (fissura pós-forame incisivo completa), com $25 \%$, e no Subgrupo III.b (fissura pós-forame incisivo incompleta), com $21 \%$.

Para que pudéssemos concluir que realmente não haviam diferenças entre as taxas de histórico familial positivo encontradas dentro de cada Subgrupo de fissura, comparamos estatisticamente, dentro de cada grupo principal (I, II e III), os Subgrupos entre si. Não foi encontrada, nesta análise, nenhuma diferença estatisticamente significativa. Este dado reforça a ideia de que, dentro dos Subgrupos comparados, de acordo com a semelhança do tipo de fissura, a chance de encontrarmos percentuais semelhantes de histórico familial positivo é grande, uma vez que não foram encontradas diferenças significativas nestas comparações. 
$\mathrm{Na}$ literatura, nenhum outro estudo apresenta uma análise tão minuciosa quanto esta apresentada neste estudo, no que se refere a quantidade de indivíduos com histórico familial positivo para diferentes tipos de fissuras labiopalatinas não sindrômicas, ou seja, os estudos publicados até o momento, analisaram, de maneira geral, algum grupo específico de FL/P e não diversos grupos, conforme proposto no presente estudo. Na literatura consultada há somente dois estudos que buscaram analisar a frequência do histórico familial positivo em indivíduos que apresentavam somente fissura transforame incisivo unilateral. $\mathrm{O}$ primeiro deles foi realizado por Yew, Alam e Rahman (2016), com 107 indivíduos com fissura transforame incisivo unilateral não sindrômica e, foi constatado que 20 sujeitos (19\%), apresentavam histórico familial positivo para esta anomalia. O segundo e mais recente estudo, realizado por Arshad, Alam e Khamis (2018) na Malásia avaliou 101 sujeitos com fissura transforame incisivo unilateral e verificou que 30 deles $(29,7 \%)$, apresentavam, pelo menos, mais um parente também acometido por esta anomalia. Ambos os estudos tiveram o tamanho amostral inferior ao nosso e, também, encontraram percentuais de histórico familial positivo inferiores. Além disso, verificamos que estes estudos não discutiram os resultados encontrados, impossibitando que fizéssemos comparações e inferências com tais informações sobre o histórico familial, uma vez que o foco desses trabalhos era no tratamento de sujeitos com fissura labiopalatina e o histórico familial era apenas um fator avaliado. Além destes dois estudos, não temos nenhum outro para comparação, uma vez que se identificou que na literatura não foram publicados, até o momento, trabalhos que investigassem essas questões familiais, envolvendo o componente genético da etiologia do defeito, detalhando os diferentes tipos anatômicos de fissuras. Após minuciosa revisão da literatura nacional e internacional, verificamos que os estudos que buscavam, como um dos seus objetivos, investigar o percentual de histórico familial positivo para as fissuras labiopalatinas não sindrômicas, apresentavam tamanho amostral pouco expressivo ou mesmo representativo. Constatamos, ainda, que o nosso estudo apresenta, como diferencial, o tamanho da amostra, pois em nenhum dos estudos encontrados o tamanho amostral foi igual e/ou superior ao utilizado no presente trabalho, isso mostra e enfatiza a relevância científica deste estudo e, ainda, reforça a importância de amostras grandes e expressivas para 
estudos que visam analisar o aspecto genético envolvido na etiologia de anomalias complexas, como é o caso das fissuras labiopalatinas não sindrômicas.

Analisando em detalhes os 825 casos de indivíduos com histórico familial positivo para as fissuras labiopalatinas, foram encontrados 1072 parentes também afetados por essa anomalia. Em 627 probandos (78\%), apenas um outro parente havia sido acometido e, em 178 haviam, ao menos, mais 2 casos de fissura na família. Nesta análise da quantidade de parentes afetados fica evidente que, mesmo diante de histórico familial positivo, a grande maioria dos casos apresenta histórico familial único. Isso nos leva a refletir quanto ao peso do componente genético na etiologia da fissura labiopalatina não sindrômica, pois quando o componente genético é um fator de impacto em uma condição, a chance dessa anomalia se repetir, dentro de uma família, é grande, porém não foi isso que encontramos neste estudo.

Estudos semelhantes, que tinham como objetivo verificar a quantidade de familiares afetados, distribuídos em famílias de sujeitos com histórico familial positivo para as fissuras labiopalatinas, não são muito detalhados. Em uma análise realizada por Salahshourifar e colaboradores (2012), na Malásia, os autores constataram que entre 23 sujeitos com histórico familial positivo para esta anomalia, 41 familiares também tinham sido acometidos pelas fissuras labiopalatinas, porém no estudo os autores não citam o número de parentes acometidos para cada caso avaliado. Um estudo brasileiro conduzido por Souza-Freitas e colaboradores (2004), verificou que em $24,78 \%$ dos sujeitos que relataram ter histórico familial positivo, havia apenas mais um caso de fissura na família, em $5,97 \%$ dos casos haviam dois casos, em $0,62 \%$ três ou quatro casos de parentes também afetados pelas FL/P e em 0,24\% dos casos, haviam 5 parentes também afetados por esta anomalia. No estudo conduzido por Garbieri (2016), avaliando casos somente de fissura pós-forame incisivo, foi constatado que 32 sujeitos, dos 41 com histórico familial positivo, apresentavam apenas um outro parente afetado pela anomalia. Estes achados da literatura, quando comparados ao encontrado no presente estudo, são similares e corroboram com a hipótese de que sujeitos com FL/PNS, com histórico familial positivo para esta anomalia, apresentam, com maior frequência, apenas um outro parente afetado. No que diz respeito a essa caracterização do histórico familial e 
buscando compreender se haveria diferença quanto ao número de parentes afetados, dependendo do tipo de fissura do probando analisado, os três grandes grupos foram estatisticamente comparados. Contudo não foram encontramos diferenças estatisticamente significativas, ou seja, isso quer dizer que nos três grupos principais, os percentuais de indivíduos com histórico familial único e múltiplo, foram semelhantes. No entanto, avaliando percentualmente o grupo II (fissuras transforame incisivo unilateral e bilateral), verifica-se que este foi o que apresentou o maior percentual de múltiplos parentes afetados, comparativamente aos demais grupos. Nesse contexto dúbio, esses dados, tanto estatísticos como percentuais precisam ser interpretados com cautela. Apesar de não haver diferença estatística, do ponto que vista prático, foi visto que entre sujeitos com fissuras mais complexas, aquelas que acometiam simultaneamente o lábio, o rebordo alveolar e o palato (fissuras transforame incisivo), nas formas unilaterais ou bilaterais, havia um percentual superior de múltiplos parentes acometidos pelas fissuras.

Quanto ao grau de parentesco do familiar também acometido pela fissura labiopalatina, um primeiro ponto que chama a atenção é o grande número de casos em que essa informação era imprecisa ou não constava nos registros dos pacientes matriculados. Em estudos de natureza retrospectiva, esse tipo de ocorrência é esperada, pois contamos com levantamento de informações de fonte secundária de dados, que é o prontuário arquivado. E além disso, a família poderia não saber realmente precisar esse tipo de informação, dependendo muitas vezes da memória de quem estava sendo inquerido. Da mesma forma, os casos em que estava registrado que o familiar acometido era um parente distante, muitas vezes, pela dificuldade do próprio probando ou do responsável precisar qual o parente havia sido acometido pela malformação, esta informação não era coletada. A partir desses dados é inviável qualquer tipo de análise ou interpretação, uma vez que há dúvida inclusive sobre a veracidade da informação fornecida pelo sujeito avaliado.

Diante da verificação desses resultados, optamos em utilizar, no detalhamento dos casos de histórico familial positivo, somente aqueles referentes a parentes caracterizados em primeiro, segundo ou terceiro grau, conforme definido por Nussbaum, Mclnnes e Willard (2016), cujas informações eram precisas e assim mais confiáveis. Outros estudos nessa mesma linha verificaram que o grau de 
parentesco mais frequentemente encontrado foi o de primeiro grau, no qual estão os genitores e os irmãos (SOUZA-FREITAS et al, 2004; REITER et al., 2015; GARBIERI, 2016). De certa forma, analisando o grau de parentesco do parente ou parentes acometidos, é possível observar que a frequência respeita o grau de parentesco, sendo mais frequente em parentes de primeiro grau, seguido de segundo grau e por fim terceiro grau. Detalhando os parentes de primeiro grau, o maior percentual é relativo aos genitores, o que seria esperado, uma vez que a fissura é caraterizada como uma condição com padrão de herança multifatorial, e uma vez que envolve predisposição genética, seria esperado certa parcela de herdabilidade. O estudo de Beaty e colaborados (2001), nos Estado Unidos, analisando o histórico familial positivo apenas para parentes em $1^{\circ} \mathrm{grau}$, corrobora com esses achados, uma vez que os autores verificaram que dos 15 casos com histórico familial positivo encontrados, em 11 pai ou mãe eram acometidos e em 4 irmão ou irmã. No entanto, o estudo de Salahshourifar e colaboradores (2012), conduzido na Malásia, constatou que dos 41 parentes afetados, 18 eram irmãos do sujeito avaliado, 9 pai ou mãe, o que difere do parentesco mais frequentemente encontrado no presente estudo.

Analisando os dados da literatura, observa-se que não existe um padrão para avaliar qual o grau de parentesco do parente afetado em relação ao probando estudado. Quando comparamos os nossos achados com a literatura, verificamos que muitos estudos consideram e utilizam nas avaliações apenas parentes de $1^{\circ} \mathrm{e}$ $2^{\circ}$ grau. Por um lado, utilizar a análise apenas de graus de parentesco próximos é melhor, pois a chance desta informação estar correta é grande. Porém, nesta dissertação, por ser um estudo único nesta magnitude e tamanho amostral, escolhemos utilizar a análise de todos os grau de parentesco, pois o nosso primeiro e principal objetivo era o de levantar a prevalência do histórico familial e, a partir disso, tentar, quando possível, verificar outros fatores que tangem esta vertente, como o grau de parentesco e o tipo de fissura encontrada no parente afetado.

Quanto a análise do tipo de fissura do parente afetado, pelos mesmos motivos explicitados para o grau de parentesco, os casos de parentesco distante e sem informação precisaram ser excluídos. Além disso, para melhor entendimento do tipo de fissura apresentado pelo parente afetado e devido à informação incompleta 
no registro do paciente, em alguns casos, quanto ao tipo de fissura no parente afetado, optamos em utilizar a classificação do tipo de fissura do parente de acordo com a classificação proposta por Spina et al. (1972), modificada por Silva Filho et al. (1992), em que os tipos de fissura poderiam estar em um dos três grandes grupos: fissura pré-forame incisivo, transforame incisivo e pós-forame incisivo. Desta forma, neste detalhamento foram utilizadas informações referentes a 324 parentes. A fissura transforame incisivo (unilateral ou bilateral), foi a mais comumente encontrada nos parentes acometidos, presente em $43,8 \%$ dos familiares, seguida pela fissura pré-forame incisivo (podendo ser completa ou incompleta, unilateral ou bilateral), presente em $34,6 \%$ da amostra total.

Souza-Freitas e colaboradores (2004), em um estudo brasileiro, também encontraram resultados semelhantes ao nosso, no que diz respeito ao tipo de fissura presente no parente afetado. Os autores verificaram que a fissura transforame incisivo, foi a mais frequente, presente em $33,9 \%$ dos parentes; seguida pela fissura pré-forame incisivo, presente em $24,78 \%$ dos sujeitos. Porém, uma fragilidade que pode ser apontada no referido estudo está relacionado a falta de especificidade da informação, uma vez que, embora tenham utilizado o método de questionário para a coleta das informações do paciente, muitos casos avaliados eram de parentesco distante e estes não foram excluídos da análise do tipo de fissura do parente afetado. Esse fato pode ser considerado uma limitação, uma vez que, durante a coleta das informações, quanto mais distante o grau de parentesco, menor a chance de a informação ser precisa, pois o levantamento destes dados depende da memória ou das lembranças do sujeito e da família. Corroborando com nossos achados, Salahshourifar e colaboradores (2012), também verificaram que o tipo de fissura mais comumente encontrado, nos parentes afetados, foi a fissura transforame incisivo.

Ao comparamos nossos resultados com o estudo europeu conduzido por Reiter e colaboradores (2015), verificamos que estes autores encontraram resultados divergentes, pois foram averiguados mais casos de parentes com fissura pós-forame incisivo (19 casos), seguido por fissura transforame incisivo (14 casos) e 5 casos de fissura pré-forame incisivo. Acreditamos que esta diferença na distribuição dos tipos de fissura encontradas no parente afetado, possa ter ocorrido 
devido ao fato de os autores terem utilizado um número maior de indivíduos diagnosticados com fissura pós-forame incisivo, completa e incompleta, quando comparado aos demais tipos de fissura. Esta informação se torna verdadeira a medida que, quando analisamos o sujeito com histórico familial positivo para as fissuras labiopalatinas, agrupados de acordo com o tipo de fissura no qual ele apresenta (separados nos 3 grupos principais: Grupo I - fissura pré-forame incisivo; Grupo II - fissura transforame incisivo; e Grupo III - fissura pós-forame incisivo) e, analisando o tipo de fissura encontrada no parente, constatamos que são encontrados mais casos de fissura pós-forame incisivo em parentes de sujeitos que também apresentam esse tipo de fissura. Desta forma, se o estudo não for delineado a partir de levantamento de informações de uma casuística equiparada em número igual de sujeitos para os três tipos principais de fissuras labiopalatinas, a chance desta informação ser tendenciosa é grande.

Ainda quanto ao padrão do tipo de fissura do probando avaliado e do parente afetado, em nosso estudo pudemos constatar que tanto no grupo de sujeitos com fissura pré-forame incisivo como no grupo com fissura transforame incisivo, o tipo de fissura mais frequentemente encontrado no parente afetado, foi a transforame incisivo. Este dado nos faz refletir acerca do padrão de ocorrência da fissura labiopalatina na família, pois na fissura pré-forame incisivo, diferente dos outros dois tipos, não houve um padrão, pois neste tipo, ao invés de verificar mais parentes com este mesmo tipo de anomalia, foi constatado um maior número de parentes com um tipo de fissura diferente do probando.

Por fim é importante destacar, nesta dissertação, a importância de estudar e detalhar o aspecto genético dessa malformação, no tocante ao histórico familial de sujeitos com fissuras labiopalatinas não sindrômicas, uma vez que diversos estudos de caso-controle, publicados na literatura, revelam diferenças estatisticamente significativas ao comparar ambos os grupos, no que diz respeito ao histórico familial para as fissuras labiopalatinas, ou seja, a chance de sujeitos com FL/PNS terem, em suas famílias, pelo menos algum outro parente afetado, é maior do que a chance de encontrar, entre sujeitos sem fissura, a anomalia na família (LI et al., 2016; NEOGI et al., 2017; MBUYI-MUSANZAYI et al., 2018) 
Também acreditamos que, para reduzir o viés em estudos futuros, aconselhamos que sejam levantados dados acerca do histórico familial por meio de entrevistas individuais com o sujeito com a anomalia e seus familiares, uma vez que fazer a análise de dados secundários nos causa prejuízos relacionados à falta de precisão nas informações mineradas. Ademais, para entender o histórico familial de sujeitos com esta anomalia congênita seria interessante também estudos futuros com uma abordagem por meio de estudo prospectivo, verificando se há novos casos desta anomalia na família de sujeitos que já são atendidos no HRAC - USP. 



\section{CONCLUSÃO}

Os resultados obtidos a partir da análise de sujeitos matriculados no Hospital de Reabilitação de Anomalias Craniofaciais da Universidade de São Paulo (HRACUSP), sugerem que:

No geral, independente do tipo de fissura labiopalatina não-sindrômica do probando avaliado, a frequência de histórico familial positivo para as fissuras foi de $31 \%$.

Os sujeitos que apresentaram as fissuras labiopalatinas mais complexas, no caso as transforame incisivo (unilateral + bilateral), foram os que apresentaram as maiores taxas percentuais de histórico familial positivo, seguido do grupo com fissura pré-forame incisivo e com menor taxa o grupo com fissura pós-forame incisivo.

Nos casos de histórico positivo, os três grandes grupos apresentavam característica de histórico familial único, ou seja, havia somente mais um caso na família. Considerando o grau de parentesco dos casos familiais classificados em primeiro, segundo e terceiro grau, o grau de parentesco mais frequentemente encontrado no parente também afetado pela fissura, independente do tipo de fissura do probando avaliado, foi o parentesco em primeiro grau.

Verificamos que na fissura transforame incisivo e na fissura pós-forame incisivo existe um padrão de ocorrência deste tipo de fissura nos outros membros da família acometidos pela malformação, porém este padrão não foi encontrado para os probandos com fissura pré-forame incisivo.

As fissuras mais complexas, no caso as transforame incisivo (unilateral + bilateral), apresentaram frequência percentual superior de histórico familial positivo para a anomalia quando comparadas as frequências percentuais entre sujeitos com fissuras pré-forame incisivo e fissuras pós-forame incisivo. 



\section{REFERÊNCIAS}





\section{REFERÊNCIAS}

Abdollahi-Fakhim S, Estiar MA, Varghaei P, Sharafi MA, Sakhinia M, Sakhinia E. Common mutations of the methylenetetrahydrofolate reductase (MTHFR) gene in non-syndromic cleft lips and palates children in North-West of Iran. Iran J Otorhinolaryngol. 2015 Jan;27(78):7-14.

Ahmed MK, Bui AH, Taioli E. Epidemiology of cleft lip and palate. Intech. 2017 Mar:122.

Aldhorae KA, Böhmer AC, Ludwig KU, Esmail AH, Al-Hebshi NN, Lippke B, et al. Nonsyndromic cleft lip with or without cleft palate in arab population: genetic analysis of 15 risk loci in a novel case-control sample recruited in Yemen. Birth Defects Res A Clin Mol Teratol. 2014 Apr;100(4):307-13.

Alvarez CW, Guion-Almeida M, Richieri-Costa A. Clinical and genetic study on 356 Brazilian patients with a distinct phenotype of cleft lip and palate without alveolar ridge involvement. J Craniomaxillof Surg. 2014 Dec;42(8):1952-7.

Aquino SN, Paranaiba LM, Martelli DR, Swerts MS, Barros LM, Bonan PR, et al. Study of patients with cleft lip and palate with consanguineous parents. Braz J Otorhinolaryngol. 2011 Jan-Feb;77(1):19-23.

Arshad Al, Alam MK, Khamis MF. Dentoalveolar cleft treatment outcome using modified huddart-bodenham index and regression analysis of associated factors. Cleft Palate Craniofac J. 2018 May;55(5):682-7.

Beaty TH, Wang H, Hetmanski JB, Fan YT, Zeiger JS, Liang KY, et al. A case-control study of nonsyndromic oral clefts in Maryland. Ann Epidemiol. 2001 Aug;11(6):43442.

Bittles $\mathrm{AH}$, Black ML. The impact of consanguinity in neonatal and infant health. Early Hum Dev. 2010 Nov;86(11):734-41.

Brito LA, Cruz LA, Rocha KM, Barbara LK, Silva CB, Bueno DF, et al. Genetic contribution for non-syndromic cleft lip with or without palate (NS CL/P) in different regions of Brazil and implications for association studies. Am J Med Genet A. 2011 Jul;155A(7):1581-7. 
Buyu Y, Manyama M, Chandika A, Gilyoma J. Orofacial clefts at Bugando Medical Centre: associated factors and postsurgical complications. Cleft Palate Craniofac J. 2012 Nov;49(6):736-40.

Cai Y, Patterson KE, Reinier F, Keesecker SE, Blue E, Bamshad M, et al. Copy number changes identified using whole exome sequencing in nonsyndromic cleft lip and palate in Honduran population. Birth Defects Res. 2017 Oct;109(16):1257-67.

Cymrot M, Sales FC, Teixeira FA, Teixeira FA Júnior, Teixeira GS, Cunha JP Filho, et al. Prevalência dos fenótipos de fissura em pacientes com fissuras labiopalatinas atendidos em um hospital pediátrico no nordeste brasileiro. Rev. Bras. Cir. Plást. 2010;25(4):648-51.

Di Ninno CQ, Fonseca LF, Pimenta MV, Vieira ZG, Fonseca JA, Miranda IC, et al. Epidemiological survey of patients with cleft lip and/or palate at a specialized center in Belo Horizonte, Brazil. Rev CEFAC. 2011 Jun;13(6):1002-8.

Esmail AH, Abdo MA, Krentz H, Lenz JH, Gundlach KK. Centre-based statistics of cleft lip with/without alveolus and palate as well as cleft palate only patients in Aden, Yemen. J Craniomaxillofac Surg. 2014 Jun;42(4):297-304.

Falagan-Lotsch P, Lopes TS, Küchler EC, Tannure PN, Costa MC, Amorim LM, et al. The functional EGF+61 polymorphism and nonsyndromic oral clefts susceptibility in a Brazilian population. J Appl Oral Sci. 2015 Jul-Aug;23(4):390-6.

Fan D, Wu S, Liu L, Xia Q, Tian G, Wang W, et al. Prevalence of non-syndromic orofacial clefts: based on 15094978 Chinese perinatal infants. Oncotarget. 2018 Jan;9(17):13981-90.

Fogh-Andersen P. Inheritance of harelip and cleft palate. Nyt Nordisk Forlag, 1942 apud Alvarez CW, Guion-Almeida ML, Richieri-Costa A. Clinical and genetic study on 356 Brazilian patients with a distinct phenotype of cleft lip and palate without alveolar ridge involvement. J Craniomaxillof Surg. 2014 Dec;42(8):1952-7.

Fontes MÍ, Almeida LN, Reis GO Júnior, Vieira JI Filho, Santos KM, Anjos FS, et al. Local strategies to address health needs of individuals with orofacial clefts in Alagoas, Brazil. Cleft Palate Craniofac J. 2013 Jul;50(4):424-31. 
Freitas JA, das Neves LT, de Almeida AL, Garib DG, Trindade-Suedam IK, Yaedú $R Y$, et al. Rehabilitative treatment of cleft lip and palate: experience of the Hospital for Rehabilitation of Craniofacial Anomalies/USP (HRAC/USP) - Part 1: overall aspects. J Appl Oral Sci. 2012 Feb;20(1):9-15.

Garbieri TF. Fissura de palato isolada não sindrômica: estudo do fenótipo, recorrência familial e histórico gestacional [dissertação]. Bauru (SP): Hospital de Reabilitação de Anomalias Craniofaciais, Universidade de São Paulo, 2016.

Gorlin RJ, Cohen MM Júnior, Levin LS. Syndromes of the head and neck. New York: Oxford University Press; 1990.

Haque S, Alam MK, Khamis MF. Factors responsible for unfavorable dental arch relationship in non syndromic unilateral cleft lip and palate children. J Clin Pediatr Dent. 2017;41(3):236-42.

Higuchi $\mathrm{Y}$, Hasegawa K, Yamashita M, Tanaka H, Tsukahara $\mathrm{H}$. A novel mutation in the COL2A1 gene in a patient with Stickler syndrome type 1: a case report and review of the literature. J Med Case Rep. 2017 Aug;11(1):237.

Holder SE, Vintiner GM, Farren B, Malcolm S, Winter RM. Confirmation of an association between RFLPs at the transforming growth factor-alpha locus and nonsyndromic cleft lip and palate. J Med Genet. 1992 Jun;29(6):390-2.

Honein MA, Rasmussen SA, Reefhuis J, Romitti PA, Lammer EJ, Sun L, et al. Maternal smiking and environmental tabacco smoke exposure and the risk of orofacial clefts. Epidemiology. 2007 Mar;18(2):226-33.

Jajja MR, Gilani A, Cawasji ZF, Imran S, Khan MS, Hashmi SS, et al. Oral clefts: a review of the cases and our experience at a single institution. J Pak Med Assoc. 2013 Sep;63(9):1098-102.

Jia ZL, He S, Jiang SY, Zhang BH, Duan SJ, Shi JY, et al. Rs12941170 at SOX9 gene associated with orofacial clefts in Chinese. Arch Oral Biol. 2017 Apr;76:14-19.

Jiang S, Shi JY, Lin YS, Duan SJ, Chen X, Jiao JJ, et al. NTN1 gene was risk to nonsyndromic cleft lip only among Han Chinese population. Oral Dis. 2019 Mar;25(2):535-42. 
Kang SL, Narayanan CS, Kelsall W. Mortality among infants born with orofacial cleft in a single cleft network. Cleft Palate Craniofac J. 2012 Jul;49(4):508-11.

Khan MF, Little J, Mossey PA, Steegers-Theunissen RP, Bonsi M, Bassi Andreasi R, et al. Association between a common missense variant in LOXL3 gene and the risk of non-syndromic cleft palate. Congenit Anom (Kyoto). 2018 Jul;58(4):136-40.

Leslie EJ, Marazita ML. Genetics of cleft lip and cleft palate. Am J Med Genet C Semin Med Genet. 2013 Nov;163C(4):246-58.

Leite IC, Koifman S. Oral clefts, consanguinity, parental tobacco and alcohol use: a case-control study in Rio de Janeiro, Brazil. Braz Oral Res. 2009 Jan-Mar;23(1):31-7.

Li H, Luo M, Luo J, Zheng J, Zeng R, Du Q, et al. A discriminant analysis prediction model of non-syndromic cleft lip with or without cleft palate based on risk factors. BMC Pregnancy Childbirth. 2016 Nov;16(1):1-8.

Mangold E, Ludwig KU, Birnbaum S, Baluardo C, Ferrian M, Herms S, et al. Genome-wide association study identifies two susceptibility loci for nonsyndromic cleft lip with or without cleft palate. Nat Genet. 2010 Jan;42(1):24-6.

Martelli DR, Machado RA, Swerts MS, Rodrigues LA, Aquino SN, Martelli H Júnior. Non syndromic cleft lip and palate: relationship between sex and clinical extension. Braz J Otorhinolaryngol. 2012 Oct;78(5):116-20.

Mbuyi-Musanzayi S, Kayembe TJ, Kashal MK, Lukasa PT, Kalenga PM, Tshilombo FK, et al. Non-syndromic cleft lip and/or palate: epidemiology and risk factors in Lubumbashi (DR Congo), a case-control study. J Craniomaxillofac Surg. 2018 Jul;46(7):1051-8.

Meira JG. Estudo clínico e molecular em pacientes com fissuras orais para avaliação do efeito fenotípico de variantes do IRF6 e estimativa da contribuição genética nas fissuras palatinas [dissertação]. São Paulo (SP): Instituto de Biociências, Universidade de São Paulo, 2014.

Menegotto BG, Salzano FM. Epidemiology of oral clefts in a large South American sample. Cleft Palate Craniofac J. 1991 Oct;28(4):373-6. 
Meng L, Bian Z, Torensma R, Von der Hoff JW. Biological mechanisms in palatogenesis and cleft palate. J Dent Res. 2009 Jan;88(1):22-33.

Mitchell LE, Beaty TH, Lidral AC, Munger RG, Murray JC, Saal HM, et al. Guidelines for design and analysis of studies on nonsyndromic cleft lip and palate in humans: summary report from a Workshop of an International Consortium for Oral Clefts Genetics. Cleft Palate Craniofac J. 2002 Jan;39(1):93-100.

Mossey PA. The heritability of malocclusion: part 1 - genetics, principles and terminology. Br J Orthod. 1999 Jun;26(2):103-13.

Mossey PA, Little J, Munger RG, Dixon MJ, Shaw WC. Cleft lip and palate. Lancet. 2009 Nov;374(9703):1773-85.

Neogi SB, Singh S, Pallepogula DR, Pant H, Kolli SR, Bharti P, et al. Risk factors for orofacial clefts in India: a case-control study. Birth Defects Res. 2017

Oct;109(16):1284-91.

Neves LT, Dionísio TJ, Garbieri TF, Parisi VA, Oliveira FV, Oliveira TM, et al. Novel rare variants in IRF6 in subjects with non-syndromic cleft lip and palate and dental agenesis. Oral Dis. 2019 Jan;25(1):223-33.

Nussbaum RL, Mcinnes RR, Willard HF. Thompson \& Thompson Genética Médica. $8^{\mathrm{a}}$ ed. Amsterdã: Elsevier; 2016.

Posnick JC, Ruiz RL. Treacher Collins syndrome: current evaluation, treatment, and future directions. Cleft Palate Craniofac J. 2000 Sep;37(5):434.

Ravichandran K, Shoukri M, Aljohar A, Shazia NS, Al-Twaijri Y, Al Jarba I. Consanguinity and occurrence of cleft lip/palate: a hospital-based registry study in Riyadh. Am J Med Geneti A. 2012 Mar;158A(3):541-6.

Reiter R, Brosch S, Lüdeke M, Fischbein E, Rinckleb A, Haase S, et al. Do orofacial clefts represent different genetic entities? Cleft Palate Craniofac J. 2015 Jan;52(1):115-20.

Rodrigues K, Sena MF, Roncalli AG, Ferreira MA. Prevalence of orofacial cleft and social factors in Brazil. Braz Oral Res. 2009 Jan-Mar;23(1):38-42. 
Sabbagh HJ, Innes NP, Sallout BI, Alamoudi NM, Hamdan MA, Alhamlan N, et al. Birth prevalence of non-syndromic orofacial clefts in Saudi Arabia and the effects of parental consanguinity. Saudi Med J. 2015 Sep;36(9):1076-83.

Salahshourifar I, Wan Sulaiman WA, Halim AS, Zilfalil BA. Mutation screening of IRF6 among families with non-syndromic oral clefts and identification of two novel variants: review of the literature. Eur J Med Genet. 2012 Jun;55(6-7):389-93.

Scapoli L, Martinelli M, Arlotti M, Palmieri A, Masiero E, Pezzetti F, et al. Genes causing clefting syndromes as candidates for non-syndromic cleft lip with or without cleft palate: a family-based association study. Eur J Oral Sci. 2008 Dec;116(6):50711.

Setó-Salvia N, Stanier P. Genetics of cleft lip and/or palate: association with other common anomalies. Eur J Med Genet. 2014 Aug;57(8):381-93.

Silva CM, Pereira MC, Queiroz TB, Neves LT. Can parental consanguinity be a risk factor for the occurrence of nonsyndromic oral cleft? Early Hum Dev. 2019 Aug;135:23-26.

Silva OG Filho, Ferrari FM Júnior, Rocha DL, Freitas JA. Classificação das fissuras lábio-palatais: breve histórico, considerações clínicas e sugestão de modificação. Rev. Bras. Cir. Plást. 1992 Mar-Apr;82(2):59-62.

Silva MA, Balderrama IF, Wobeto AP, Weneck RI, Azevedo-Alanis LR. The impact of nonsyndromic cleft lip with or without cleft palate on oral health-related quality of life. J Appl Oral Sci. 2018 Apr;26:1-6.

Souza-Freitas JA, Dalben GS, Freitas PZ, Santamaria M Júnior. Tendência familial das fissuras lábio-palatais. Rev. Dent. Press Ortodon. Ortop. Facial. 2004 SepOct;9(5):74-8.

Spina V, Psillakis JM, Lapa FS, Ferreira MC. Classificação das fissuras lábiopalatinas: sugestão de modificação. Rev Hosp Clin Fac Med São Paulo. 1972;27(1):5-6.

Stevenson RE, Hall JG, Everman DB, Solomon BD. Human malformations and related anomalies. 3rd ed. New York: Oxford University Press; 1993. 
Tessier P. Anatomical classification facial, cranio-facial an latero-facial clefts. J Maxillofac Sueg. 1976 Jun;4(2):69-92.

Trindade IE, Silva OG Filho. Fissuras labiopalatinas: uma abordagem interdisciplinar. São Paulo: Santos Editora; 2007.

Van der Meulen JC, Mazzika R, Vermey-Keers C, Stricker M, Raphael B. A morphogenetic classification of craniofacial malformations. Plast Reconstr Surg. 1983 Apr;71(4):560-72.

Vieira AR. Unraveling human cleft lip and palate research. J Dent Res. 2008 Feb;87(2):119-25.

Zapata AM, Palacio AM, Puerta GM, Álvarez GU. A retrospective characterization study on patients with oral clefts in Medellín, Colombia, South America. Rev Fac Odontol Univ Antioq. 2010 Jul-Dec;22(1):81-7.

Zeng N, Wu J, Zhu WC, Shi B, Jia ZL. Evaluation of the association of polymorphism in EYA1, environmental factors, and non-syndromic orofacial clefts in Western Han Chinese. J Oral Pathol Med. 2015 Nov;44(10):864-9.

Zhang BH, Shi JY, Lin YS, Shi B, Jia ZL. VAX1 gene associated non-syndromic cleft lip with or without palate in Western Han Chinese. Arch Oral Biol. 2018 Nov;95:40-3.

Yew CC, Alam MK, Rahman SA. Multivariate analysis on unilateral cleft lip and palate treatment outcome by EUROCRAN index: a retrospective study. Int J Pediatr Otorhinolaryngol. 2016 Oct;89:42-9.

Yu W, Serrano M, Miguel SS, Ruest LB, Svoboda KK. Cleft lip and palate genetics and application in early embryological development. Indian J Plast Surg. 2009 Oct;42:S35-50. 

ANEXOS 



\section{ANEXO 1 - PARECER DO COMITÊ DE ÉTICA (CEP)}

USP - HOSPITAL DE
REABILITAÇÃO DE
ANOtoforma
Profil

\section{PARECER CONSUBSTANCIADO DO CEP}

\section{DADOS DA EMENDA}

Título da Pesquisa: Investigação histórico familial entre sujeitos com diferentes tipos de fissuras orofaciais não sindrômicas

Pesquisador: Carolina Maia Silva

Área Temática: Genética Humana:

(Trata-se de pesquisa envolvendo Genética Humana que não necessita de análise ética por parte da CONEP;);

Versão: 2

CAAE: 13450419.2 .0000 .5441

Instituição Proponente: Hospital de Reabilitação de Anomalias Craniofaciais da USP

Patrocinador Principal: Financiamento Próprio

\section{DADOS DO PARECER}

Número do Parecer: 3.360 .674

\section{Apresentação do Projeto:}

O projeto intitulado "Investigação histórico familial entre sujeitos com diferentes tipos de fissuras orofaciais não sindrômicas" trata-se de projeto dissertação de mestrado da aluna Carolina Maia Silva sob orientação da Profa. Lucimara Teixeira das Neves. O projeto tem como objetivo primário, investigar o histórico familial para fissuras orofaciais entre sujeitos com diferentes tipos de fissuras labiopalatinas não sindrômica. A hipótese apresentada é de que as fissuras mais complexas, no caso as transforame incisivo unilateral e bilateral, apresentam frequência superior de histórico familial positivo para a anomalia quando comparadas as frequências entre sujeitos com fissuras de lábio isolada e fissuras de palato isolada.

Segundo os autores, a metodologia proposta consiste em:

Estudo transversal observacional descritivo, do tipo retrospectivo, de caráter exploratório, onde serão levantadas as informações, por meio de fonte secundária de dados, sobre o histórico familial para as fissuras orofaciais entre sujeitos com diferentes tipos de fissuras orofaciais divididos nos seguintes grupos: Grupo I: Fissura Transforame Incisivo Unilateral; Grupo II: Fissura Transforame Incisivo Bilateral; Grupo III: Fissura de Lábio Isolada Completa Unilateral; Grupo IV: Fissura de Lábio Isolada Completa Bilateral; Grupo V: Fissura de Lábio Isolada Incompleta Unilateral; Grupo VI:

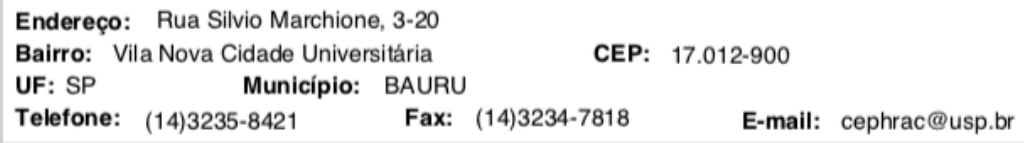




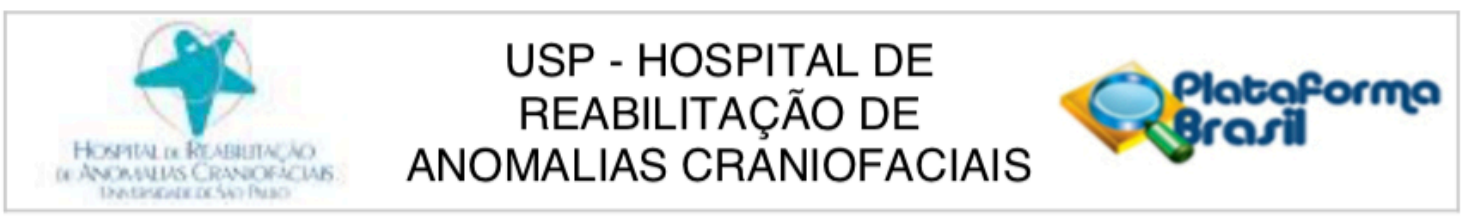

Continuação do Parecer: 3.360 .674

Fissura de Lábio Isolada Incompleta Bilateral; Grupo VII: Fissura de Palato Isolada Completa; Grupo VIII: Fissura de Palato Isolada Incompleta; Grupo IX: Associação entre diferentes tipos de Fissuras. Para determinar o tamanho da amostra, foi realizado um cálculo amostral considerando uma frequência média de histórico familial positivo para os diferentes tipos de fissura em $32 \%$, conforme estudos brasileiros (SouzaFreitas et al., 2004; Leite; Koifman, 2009; Brito et al., 2011; Fontes et al., 2013; Falagan-Lotsch et al., 2015),

com intervalo de confiança de $95 \%$ e erro amostral de $5 \%$.

O tamanho estimado da amostra, após o cálculo estatístico, foi de 335 sujeitos em cada grupo. Dessa forma, a proposta é avaliar 335 sujeitos em cada um dos 9 grupos propostos, totalizando uma amostra de 3015 sujeitos com fissuras orofaciais não sindrômicas.Inicialmente, para seleção da amostra, será feito o levantamento, junto ao Centro de Processamento de Dados (CPD) do HRAC-USP, de todos os indivíduos matriculados no hospital com diagnóstico de fissura não sindrômica confirmado para cada um dos grupos de fissura anteriormente descritos. Serão selecionados, aleatoriamente, 335 sujeitos em cada um dos grupos estabelecidos.A fim de verificar se o sujeito se enquadra nos critérios pré-estabelecidos para a pesquisa, para que seja confirmada a inclusão de cada caso, o pesquisador irá consultar inicialmente o diagnóstico descrito no prontuário do paciente.

Dos casos selecionados, serão analisadas as informações, provenientes de fontes secundárias de dados, registradas nos prontuários arquivados no HRAC-USP, onde serão coletadas informações referentes a identificação do paciente e referentes ao histórico familial.Para a identificação do sujeito serão levantadas informações referentes ao número de registro no HRAC, data de nascimento; idade; sexo; raça; e, naturalidade. No levantamento do histórico familial serão coletadas informações sobre ocorrência de anomalias craniofaciais na família do sujeito avaliado e, quando houver histórico positivo para a malformação, mineraremos os dados relativos ao grau de parentesco e o tipo de fissura do familiar acometido. As informações obtidas dos sujeitos utilizados na pesquisa serão analisadas na forma anônima e os resultados serão apresentados de forma agregada, na qual os casos incluídos não serão identificados. Essas informações serão anotadas e tabuladas em uma planilha no programa Microsoft Office Excel 2013 e serão analisadas por meio de estatística descritiva e comparativa.

\section{Objetivo da Pesquisa:}

Segundo os pesquisadores, os objetivos são os seguintes:

Objetivo Primário:

Investigar o histórico familial para fissuras orofaciais entre sujeitos com diferentes tipos de

Endereço: Rua Silvio Marchione, $3-20$
$\begin{aligned} & \text { Bairro: Vila Nova Cidade Universitária } \\ & \text { UF: SP }\end{aligned}$
$\begin{array}{lllll}\text { Município: } & \text { BAURU } & \text { CEP: } 17.012-900 & \\ \text { Telefone: } & \text { (14)3235-8421 } & \text { Fax: } & \text { (14)3234-7818 } & \text { E-mail: cephrac@usp.br }\end{array}$




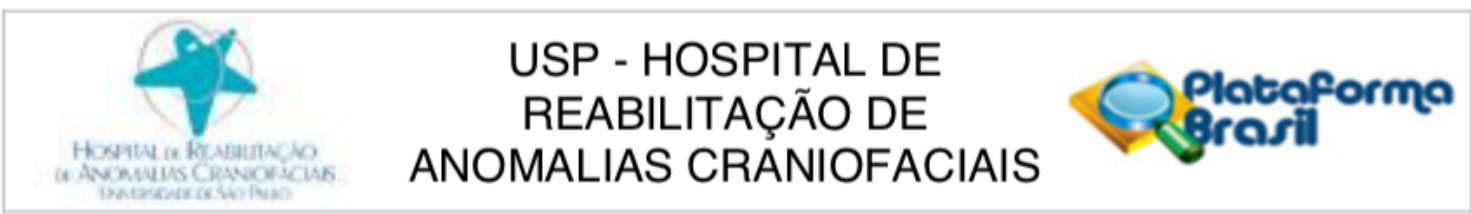

Continuação do Parecer : 3.360 .674

fissuras labiopalatinas não sindrômica.

Objetivo Secundário:

Nos casos de histórico familial positivo para as fissuras, descrever, se possível, o grau de parentesco e o tipo de fissura do familiar afetado em relação ao sujeito avaliado, buscando estabelecer se existe um padrão para os tipos de fissura encontrados nos familiares que antecederam os casos estudados e o probando em questão, com o intuito de verificar se há alguma relação entre os tipos de fissura pré-existentes naquela família e a severidade da anomalia no probando estudado.

\section{Avaliação dos Riscos e Benefícios:}

Segundo os autores:

Quanto aos riscos:

O presente projeto de pesquisa não apresenta risco ao participante uma vez que irá utilizar informações provenientes de fonte secundária de dados.

Quanto aos benefícios:

Os benefícios indiretos desta pesquisa estão relacionados a um maior conhecimento a respeito da etiologia das fissuras labiopalatinas não sindrômicas, no que diz respeito ao componente genético envolvido, especialmente relativo ao histórico familial para as fissuras orofaciais. Além disso, essa pesquisa trará grande benefício para a comunidade científica, uma vez que descreverá as características da população atendida pelo HRAC-USP, quanto a recorrência para essa anomalia entre os diferentes tipos de fissura. Ademais, entender o histórico familial de sujeitos com diferentes tipos de fissuras, poderá possibilitar abordagem de aconselhamento mais direcionada a essa população.

\section{Comentários e Considerações sobre a Pesquisa:}

Trata-se de projeto com significância clínica e mérito acadêmico. Não apresenta nenhum impedimento ético. Os pesquisadores solicitam a dispensa da utilização do Termo de Consentimento Livre e Esclarecido (TCLE), tendo em vista que o mesmo será feito a partir de um estudo retrospectivo e utilizará somente dados a partir da investigação de prontuários com informações de pacientes diagnosticados com fissura de lábio e/ou palato não sindrômicas.

\section{Considerações sobre os Termos de apresentação obrigatória:}

Carta de encaminhamento: de acordo

Formulário HRAC: de acordo

Folha de Rosto da Plataforma Brasil: de acordo

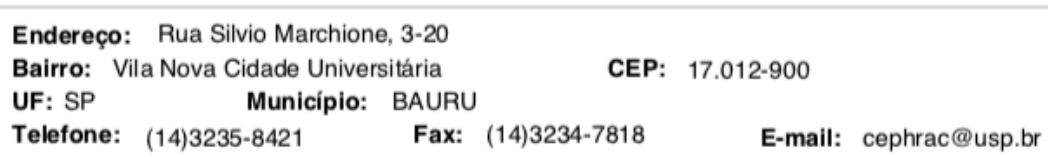




\section{USP - HOSPITAL DE REABILITAÇÃO DE ANOMALIAS CRANIOFACIAIS}

Continuação do Parecer: 3.360 .674

Justificativa de Dispensa de TCLE: de acordo

Termo de Cessão de Dentes Humanos;

Termo de Compromisso, Confidencialidade e Autorização de Utilização de Dados em Projetos de Pesquisa: de acordo

Termo de Permissão para uso de Registros para Fins Científicos: de acordo

Termo de Compromisso de Tornar Públicos os Resultados da Pesquisa e Destinação de Materiais ou Dados Coletados: de acordo

Termo de Compromisso do Pesquisador Responsável: de acordo

\section{Recomendações:}

Verificar alguns erros gramaticais e construção de algumas sentenças como o próprio título:Investigação histórico familial entre sujeitos com diferentes tipos de fissuras orofaciais não sindrômicas,em que sugere:se: Investigação DO histórico familial entre sujeitos com diferentes tipos de fissuras orofaciais não sindrômicas.

Considerar que se for utilizar imagens para ilustrar o histórico familial de pacientes com fissura, termo de consentimento para utilização de imagens é necessário.

\section{Conclusões ou Pendências e Lista de Inadequações:}

Recomendo ao colegiado, a aprovação do projeto.

\section{Considerações Finais a critério do CEP:}

O pesquisador deve atentar que o projeto de pesquisa aprovado por este CEP refere-se ao protocolo submetido para avaliação. Portanto, conforme a Resolução CNS 466/12, o pesquisador é responsável por "desenvolver o projeto conforme delineado", se caso houver alterações nesse projeto, este CEP deverá ser comunicado em emenda via Plataforma Brasil, para nova avaliação.

Cabe ao pesquisador notificar via Plataforma Brasil o relatório final para avaliação. Os Termos de Consentimento Livre e Esclarecidos e/ou outros Termos obrigatórios assinados pelos participantes da pesquisa deverão ser entregues ao CEP. Os relatórios semestrais devem ser notificados quando solicitados no parecer.

Este parecer foi elaborado baseado nos documentos abaixo relacionados:

\begin{tabular}{|l|l|c|c|c|}
\hline \multicolumn{1}{|c|}{ Tipo Documento } & \multicolumn{1}{|c|}{ Arquivo } & Postagem & Autor & Situação \\
\hline Informações Básicas & PB_INFORMAÇÕES_BÁSICAS_136955 & $31 / 05 / 2019$ & & Aceito \\
do Projeto & 6_E1.pdf & $11: 26: 26$ & & \\
\hline Outros & Checklist_Prot_Pesq_38_2019.pdf & $10 / 05 / 2019$ & Rafael Mattos de & Aceito \\
\hline
\end{tabular}

Endereço: Rua Silvio Marchione, 3-20

Bairro: Vila Nova Cidade Universitária

UF: SP Município: BAURU

Telefone: (14)3235-8421 Fax: (14)3234-7818 E-mail: cephrac@usp.br 


\section{USP - HOSPITAL DE REABILITAÇÃO DE ANOMALIAS CRANIOFACIAIS}

Continuação do Parecer: 3.360 .674

\begin{tabular}{|l|l|c|l|c|}
\hline Outros & Checklist_Prot_Pesq_38_2019.pdf & $12: 01: 15$ & Deus & Aceito \\
\hline Recurso Anexado & Recursos_Orcamento.pdf & $09 / 05 / 2019$ & Carolina Maia Silva & Aceito \\
pelo Pesquisador & & $09: 34: 00$ & & \\
\hline Cronograma & Cronograma.pdf & $16: 31: 55$ & Carolina Maia Silva & Aceito \\
\hline Outros & Term_Comp_Tornar_Publico_Dest_Mat. & $09 / 05 / 2019$ \\
& $16: 29: 28$ & Carolina Maia Silva & Aceito \\
\hline Outros & Term_Comp_Pesq_Resp.pdf & $09 / 05 / 2019$ & Carolina Maia Silva & Aceito \\
& & $16: 28: 38$ & & \\
\hline Outros & Term_Comp_Conf_Aut_Dados.pdf & $09 / 05 / 2019$ & Carolina Maia Silva & Aceito \\
\hline Outros & Carta_Encaminhamento.pdf & $09 / 05 / 2019$ & Carolina Maia Silva & Aceito \\
\hline TCLE / Termos de & Justificativa_Dispensa_TCLE.pdf & $09 / 05 / 2019$ & Carolina Maia Silva & Aceito \\
Assentimento / & & $16: 20: 21$ & & \\
Justificativa de & & & & Aceito \\
Ausência & & $09 / 05 / 2019$ & Carolina Maia Silva & \\
\hline Projeto Detalhado / & Projeto.pdf & $16: 19: 16$ & & Aceito \\
Brochura \\
Investigador
\end{tabular}

\section{Situação do Parecer:}

Aprovado

\section{Necessita Apreciação da CONEP:}

Não

BAURU, 31 de Maio de 2019

\section{Assinado por:}

Renata Paciello Yamashita

(Coordenador(a))

Endereço: Rua Silvio Marchione, 3-20

Bairro: Vila Nova Cidade Universitária

UF: SP Município: BAURU

Telefone: (14)3235-8421 Fax: (14)3234-7818 E-mail: cephrac@usp.br 